Portland State University

PDXScholar

Fall 10-28-2013

\title{
Methyl Halide Production by Calcareous Periphyton Mats from the Florida Everglades
}

Ann Eileen Raffel

Portland State University

Follow this and additional works at: https://pdxscholar.library.pdx.edu/open_access_etds

Part of the Atmospheric Sciences Commons, and the Fresh Water Studies Commons Let us know how access to this document benefits you.

\section{Recommended Citation}

Raffel, Ann Eileen, "Methyl Halide Production by Calcareous Periphyton Mats from the Florida Everglades" (2013). Dissertations and Theses. Paper 1524.

https://doi.org/10.15760/etd.1523

This Thesis is brought to you for free and open access. It has been accepted for inclusion in Dissertations and Theses by an authorized administrator of PDXScholar. Please contact us if we can make this document more accessible: pdxscholar@pdx.edu. 
Methyl Halide Production by Calcareous Periphyton Mats from the Florida Everglades

\title{
by
}

\section{Ann Eileen Raffel}

A thesis submitted in partial fulfillment of the requirements for the degree of

\section{Master of Science}

in

Biology

\author{
Thesis Committee: \\ Todd Rosenstiel, Chair \\ Ronald D. Jones \\ Andrew L. Rice \\ Kenneth M. Stedman
}

Portland State University

2013 
C2013 Ann Eileen Raffel 


\begin{abstract}
Methyl halides are trace gases with both natural and anthropogenic origins. Once generated, these gases transport chlorine and bromine into the stratosphere, where they play an important role in ozone depleting catalytic cycles. The Florida Everglades is one location where methyl halide emissions have been proposed to be elevated due to high primary production and ionic halogens. This region also provides a unique study environment due to salt water intrusions, which occur during storm or low marsh water level-high tide events. The purpose of this research was twofold. First, quantification of methyl chloride $\left(\mathrm{CH}_{3} \mathrm{Cl}\right)$ and methyl bromide $\left(\mathrm{CH}_{3} \mathrm{Br}\right)$ production from periphyton mats on a temporal scale was needed. Secondly, to determine how varying concentrations of salinity affect $\mathrm{CH}_{3} \mathrm{Cl}$ and $\mathrm{CH}_{3} \mathrm{Br}$ production originating from calcareous periphyton mats within the Everglades. Periphyton was exposed to continuous 12 hour dark/light cycles in varying concentrations of salt water $(0,0.1,1,5$, and $10 \%$ ). All water samples were analyzed to determine the production rate of $\mathrm{CH}_{3} \mathrm{Cl}$ and $\mathrm{CH}_{3} \mathrm{Br}$ in periphyton samples using a gas chromatograph coupled with an electron capture detector (GC-ECD). Periphyton mats were found to be a producer of $\mathrm{CH}_{3} \mathrm{Cl}$ in all freshwater $(0 \%$ ) trials and sampling times; however, results from $\mathrm{CH}_{3} \mathrm{Br}$ analysis found production rates that suggest consumption occurred in the majority of the $0 \%$ trials. Production rates for $\mathrm{CH}_{3} \mathrm{Cl}$ ranged from 0.077 to $0.109 \mathrm{pM} \mathrm{g}^{-1} \mathrm{hr}^{-1}$ after 24 hours, 0.027 to $0.073 \mathrm{pM} \mathrm{g}^{-1} \mathrm{hr}^{-1}$ after 48 hours, and 0.034 to $0.047 \mathrm{pM} \mathrm{g}^{-1} \mathrm{hr}^{-1}$ after 72 hours. Production rates for the $\mathrm{CH}_{3} \mathrm{Br}$ freshwater experiments ranged from -0.00025 to $0.00185 \mathrm{pM} \mathrm{g}^{-1} \mathrm{hr}^{-1}$ after 24
\end{abstract}


hours, -0.00022 to $-0.00078 \mathrm{pM} \mathrm{g}^{-1} \mathrm{hr}^{-1}$ after 48 hours, and -0.00042 to $-0.00061 \mathrm{pM} \mathrm{g}^{-1}$ $\mathrm{hr}^{-1}$ after 72 hours. This research has also shown that increased salinity does have a significant positive effect on the production of $\mathrm{CH}_{3} \mathrm{Cl}$ and $\mathrm{CH}_{3} \mathrm{Br}$ from calcareous periphyton mats, which is important in areas that could be prone to salt water intrusions or rising sea levels due to global climate change. 


\section{Dedication}

To my mom and dad 


\section{Acknowledgments}

I would like to thank everyone who has provided me with help, guidance, and suggestions throughout this endeavor including: Dr. Ron Jones, my advisor, Dr. Norman Scully, my thesis committee: Dr. Andrew Rice, Dr. Todd Rosenstiel, and Dr. Ken Stedman, and Dr. Chris Butenhoff for all his help with the modeling aspect of this project.

Lastly, this research would not have been possible without the funding provided by the National Science Foundation Chemical Oceanography Program Award No.1029710. I would also like to thank Dr. Richard Gammon for the use of instrumentation and Dr. Evelyn Gaiser for technical support in field sampling. 


\section{Table of Contents}

Page

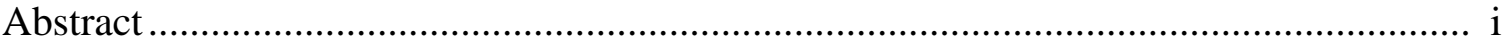

Dedication

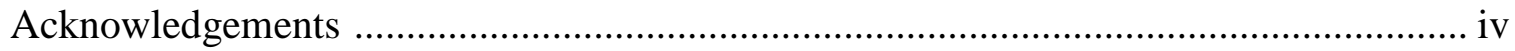

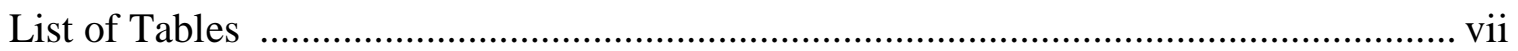

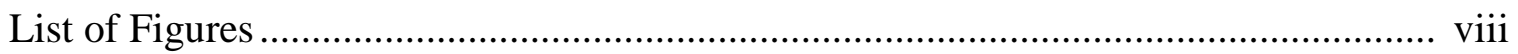

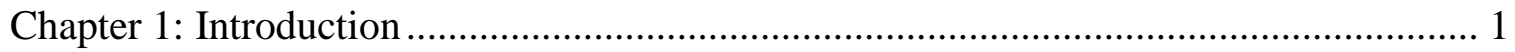

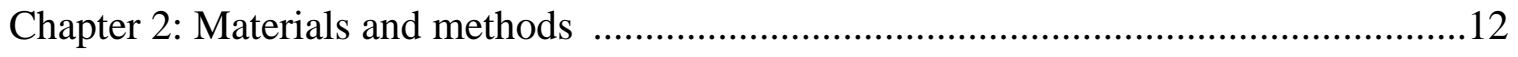

Study sites and periphyton sampling ................................................. 12

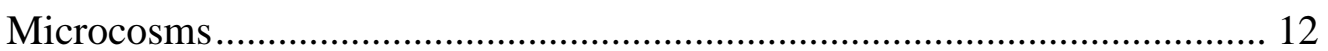

Experimental methods ................................................................. 13

Gas chromatograph with electron capture detector (GC-ECD) ................... 15

Modifications to the pre-concentration system................................ 15

Modifications to the GC-ECD ...................................................... 16

Moisture and oxygen purifier/traps.............................................. 16

Calibration curves ................................................................... 17

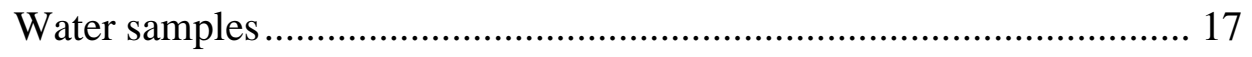

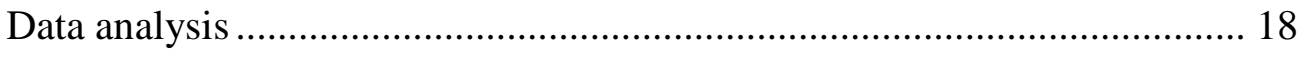

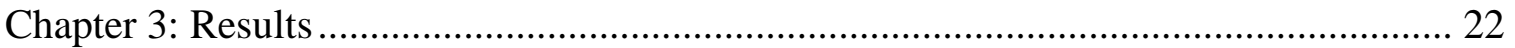

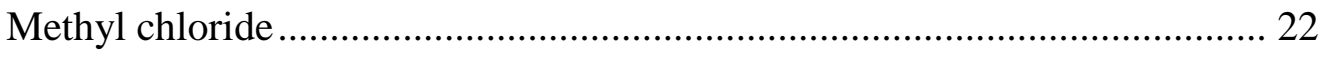


Methyl bromide.

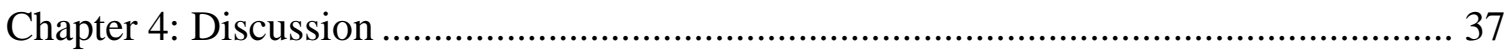

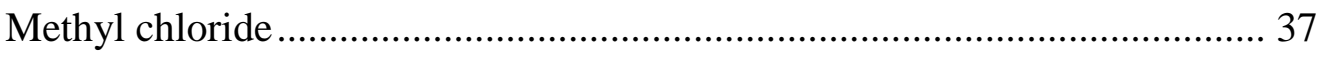

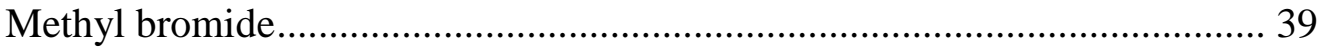

Comparisons to other methyl halide studies ..................................................41

Modeling and climate change ................................................................ 42

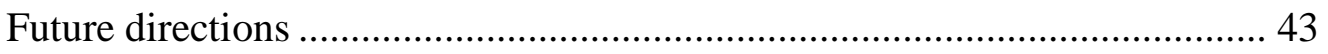

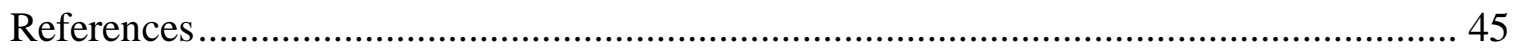

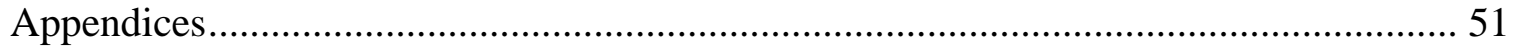

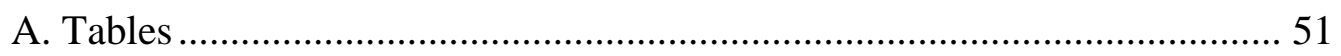

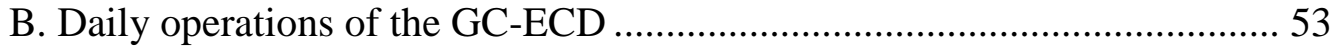




\section{List of Tables}

Table number $\quad$ Page

1.1 Estimated source and sink strengths $(\mathrm{Gg} / \mathrm{yr})$ for methyl chloride $\left(\mathrm{CH}_{3} \mathrm{Cl}\right)$. ............10

1.2 Estimated source and sink strengths $(\mathrm{Gg} / \mathrm{yr})$ for methyl bromide $\left(\mathrm{CH}_{3} \mathrm{Br}\right)$. ...........11

3.1 Average values for $0 \%$ (freshwater) experiments for methyl chloride $\left(\mathrm{CH}_{3} \mathrm{Cl}\right)$ concentrations and production over time for all trials. Standard deviations are noted.

3.2 Average values for $0.1 \%$ experiments for methyl chloride $\left(\mathrm{CH}_{3} \mathrm{Cl}\right)$ concentrations and production over time for all trials. Standard deviations are noted.

3.3 Average values for $1 \%$ oxperiments for methyl chloride $\left(\mathrm{CH}_{3} \mathrm{Cl}\right)$ concentrations and production over time for all trials. Standard deviations are noted.

3.4 Average values for 5\%o experiments for methyl chloride $\left(\mathrm{CH}_{3} \mathrm{Cl}\right)$ concentrations and production over time for all trials. Standard deviations are noted.

3.5 Average values for $10 \%$ experiments for methyl chloride $\left(\mathrm{CH}_{3} \mathrm{Cl}\right)$ concentrations and production over time for all trials. Standard deviations are noted.

3.6 Average values for $0 \%$ o (freshwater) experiments for methyl bromide $\left(\mathrm{CH}_{3} \mathrm{Br}\right)$ concentrations and production over time for all trials. Standard deviations are noted.

3.7 Average values for $0.1 \%$ experiments for methyl bromide $\left(\mathrm{CH}_{3} \mathrm{Br}\right)$ concentrations and production over time for all trials. Standard deviations are noted.

3.8 Average values for $1 \%$ oxperiments for methyl bromide $\left(\mathrm{CH}_{3} \mathrm{Br}\right)$ concentrations and production over time for all trials. Standard deviations are noted.

3.9 Average values for 5\%o experiments for methyl bromide $\left(\mathrm{CH}_{3} \mathrm{Br}\right)$ concentrations and production over time for all trials. Standard deviations are noted.

3.10 Average values for $10 \%$ oxperiments for methyl bromide $\left(\mathrm{CH}_{3} \mathrm{Br}\right)$ concentrations and production over time for all trials. Standard deviations are noted. 


\section{List of Figures}

Figure number $\quad$ Page

1.1 Diagram and reaction pathways for ozone destruction cycles.............................. 9

2.1 Map of the Florida Everglades, U.S.A. with periphyton sampling sites (TS 2 and 3) circled.

2.2 Periphyton microcosms in the research greenhouse ......................................... 19

2.3 Quartz tube with periphyton and attached stopcock valve. ............................... 20

2.4 Schematic diagram for GC-ECD for methyl halide analysis............................... 21

3.1 Methyl chloride $\left(\mathrm{CH}_{3} \mathrm{Cl}\right)$ production by periphyton, over time, for $0 \%$ (A), $0.1 \% \circ(\mathrm{B}), 1 \% \circ(\mathrm{C}), 5 \%$ (D), and $10 \%$ (E) salt water treatments $(\mathrm{n}=3$ for each treatment). Standard deviations are noted.

3.2 Methyl chloride production $\left(\mathrm{pM} \mathrm{g}^{-1} \mathrm{hr}^{-1}\right.$ ) for one trial from each salt water Treatment. All salt water treatments except for the 5\%o were performed during October 2012. 5\%o trial was completed in February 2013 ................................... 28

3.3 The relationship between methyl chloride $\left(\mathrm{CH}_{3} \mathrm{Cl}\right)$ production and salinity $(n=44)$. Standard deviations are noted.

3.4 Methyl bromide $\left(\mathrm{CH}_{3} \mathrm{Br}\right)$ production by periphyton, over time, for $0 \%$ o (A), $0.1 \% \circ(\mathrm{B}), 1 \% \circ(\mathrm{C}), 5 \% \circ(\mathrm{D})$, and $10 \%$ (E) salt water treatments $(\mathrm{n}=3$ for each treatment). Standard deviations are noted.

3.5 The relationship between methyl bromide $\left(\mathrm{CH}_{3} \mathrm{Br}\right)$ production and salinity $(n=42)$. Standard deviations are noted. 


\section{Chapter 1}

\section{Introduction}

Methyl halides (methyl chloride, $\mathrm{CH}_{3} \mathrm{Cl}$; methyl bromide, $\mathrm{CH}_{3} \mathrm{Br}$; and methyl iodide, $\left.\mathrm{CH}_{3} \mathrm{I}\right)$ are trace gases with natural and anthropogenic origins. The majority of methyl halides are formed naturally by the photodecomposition of organic matter, in the presence of iron and halide ions, or produced by enzyme mediated methyl transferase reactions (Manley 2002; White et al. 2005; Manley et al. 2006). Once generated, these gases transport chlorine, bromine, and iodide into the stratosphere, where the chloride and bromide play an important role in ozone depleting catalytic cycles (Bulter 2000; Haust 2007). However, methyl iodide does not cause significant stratospheric ozone depletion and therefore will not be discussed in greater detail (Ennis 2007; Blei 2010).

The ozone layer found within the stratosphere plays a vital role within our planet's atmosphere. It serves as a protective blanket that shields Earth by absorbing the majority of the sun's medium range frequency ultraviolet rays (280nm to $320 \mathrm{~nm})$, which are also known as UV-B rays (Caldwell and Flint 1994). If the ozone layer was destroyed or reduced, the sun's UV-B rays would be able to reach further into our planet's atmosphere causing adverse effects for all life, such as increased frequency of skin diseases (Popov et al. 2005), reduced bacterial activity in the oceans (Herndl et al. 1993), molecular damage to nucleic acids, lipids, and proteins (Hader et al. 2003), and

reduced biomass productivity in aquatic food webs (Hader et al. 2003; Hader et al. 2007).

The cycle for ozone $\left(\mathrm{O}_{3}\right)$ destruction starts when methyl chloride or methyl 
bromide is exposed to ultraviolet light in the stratosphere and the methyl group $\left(\mathrm{CH}_{3}\right)$ is separated from either chloride or bromide forming free halogen radicals $(\mathrm{Cl}, \mathrm{Br})$. The chlorine and bromine radicals are then involved in catalytic cycles which convert ozone $\left(\mathrm{O}_{3}\right)$ to oxygen gas $\left(\mathrm{O}_{2}\right)$ (Figure 1) (Fahey 2007; Blei 2010). These cycles in turn regenerate the catalyst(s) $(\mathrm{Cl}, \mathrm{Br})$ causing the cycle to start anew, allowing for further ozone destruction. In addition, both compounds have a moderately long atmospheric lifetime with methyl chloride lasting around 1 year and methyl bromide around 0.8 years (Huset 2007; Rhew 2011). Bromine is also 45-60 times more effective at destroying ozone than chlorine on a per atom basis (Daniel et al. 2007; Haust 2007).

Methyl halides are generating concern because of their ability to contribute to stratospheric ozone loss through the ozone depleting cycles (Harper 2000; Manley 2002; Hamilton et al. 2003). Currently, methyl chloride and methyl bromide contribute $\sim 15-20 \%$ and $\sim 40 \%$ of the stratospheric chloride and bromide, respectively (Harper 2000; Montzka and Reimann 2010; Parsons 2011). Because these catalytic cycles have been altered by humans, anthropogenic sources of methyl halides, in particular methyl bromide, are currently being regulated under the Montreal Protocol and its amendments (Redeker et al. 2000; Redeker et al. 2004; Williams et al. 2007). Consequently, anthropogenic sources of methyl halides are decreasing. For instance, before the Montreal Protocol, anthropogenic sources such as fumigation, both dispersive for soils and quarantine/pre-shipment, and leaded gasoline, which contains brominated compounds that when combusted release methyl bromide, made up a third of the annual methyl bromide emissions (Thomas et al. 1997; Haust 2007; Montzka and Reimann 
2010). Due to current regulations, anthropogenic sources of methyl halides are decreasing from the above mentioned sources (Montzka and Reimann 2010). This reduction is especially apparent in the Scientific Assessment of Ozone Depletion of 2010 , which states that fumigation contributed an estimated total of $49.4 \mathrm{Gg} / \mathrm{yr}$ in methyl bromide emissions from 1996-1998, but in 2008 the total dropped to $14.3 \mathrm{Gg} / \mathrm{yr}$ (Montzka and Reimann 2010). Leaded gasoline also follows a similar trend in the reduction of methyl bromide emissions with $5.7 \mathrm{Gg} / \mathrm{yr}$ from 1996-1998 and less than 5.7 Gg/yr reported in 2008 (Montzka and Reimann 2010). However, further studies that specifically address natural sources of methyl halides are required to better understand their roles in the global methyl halide budget.

Current known sources of methyl chloride include tropical/subtropical vegetation (820 to 8200 Gg/yr) (Clerbaux and Cunnold 2007; Montzka and Reimann 2010), tropical senescent or dead leaves (30-2500 Gg/yr) (Clerbaux and Cunnold 2007; Montzka and Reimann 2010), biomass burning (325 to 1135 Gg/yr) (Clerbaux and Cunnold 2007), oceans (400-600 Gg/yr) (Clerbaux and Cunnold 2007; Montzka and Reimann 2010), fungi (43 to $470 \mathrm{Gg} / \mathrm{yr}$ ) (Clerbaux and Cunnold 2007), salt marshes (50-440 Gg/yr) (Clerbaux and Cunnold 2007; Montzka and Reimann 2010), wetlands (48 Gg/yr) (Clerbaux and Cunnold 2007), mangroves (11 Gg/yr) (Montzka and Reimann 2010), rice paddies (2.4 to $4.9 \mathrm{Gg} / \mathrm{yr}$ ) (Clerbaux and Cunnold 2007), and a variety of anthropogenic sources such as coal combustion or incineration (30 to $290 \mathrm{Gg} / \mathrm{yr}$ ) (Clerbaux and Cunnold 2007; Montzka and Reimann 2010) (Table 1.1). The main sink for methyl chloride is the reaction with the hydroxyl radical (3180 to $4100 \mathrm{Gg} / \mathrm{yr}$ ). Additional 
known sinks include loss to the stratosphere (100 to $300 \mathrm{Gg} / \mathrm{yr}$ ), marine boundary layer chloride reactions (93 to $370 \mathrm{Gg} / \mathrm{yr}$ ), microbial soil degradation (100 to $1600 \mathrm{Gg} / \mathrm{yr}$ ), and loss to cold polar ocean waters (93 to $145 \mathrm{Gg} / \mathrm{yr}$ ) (Clerbaux and Cunnold 2007; Montzka and Reimann 2010) (Table 1.1).

Methyl bromide sources include, but are not limited to, fumigation, both dispersive and quarantine/pre-shipment (11.7 to $17.1 \mathrm{Gg} / \mathrm{yr}$ ), ocean (34 to $49 \mathrm{Gg} / \mathrm{yr}$ ), biomass burning ( 10 to $40 \mathrm{Gg} / \mathrm{yr}$ ), coastal salt marshes ( 0.2 to $29 \mathrm{Gg} / \mathrm{yr}$ ), rapeseed (4.0 to $6.1 \mathrm{Gg} / \mathrm{yr}$ ), and fungi (1 to $5.7 \mathrm{Gg} / \mathrm{yr}$ ). Sinks of methyl bromide consist of the ocean (45 to $52 \mathrm{Gg} / \mathrm{yr}$ ), hydroxyl radial and photolysis reaction ( $63.6 \mathrm{Gg} / \mathrm{yr}$ ), and soils (19 to 44 Gg/yr) (Montzka and Reimann 2010) (Table 1.2).

It has been determined that $30 \%$ of the total stratospheric ozone loss attributed to methyl halides is due to natural sources (Wayne 2000; Blei 2010). Therefore, it would be beneficial to have an accurate knowledge of the global methyl halide budget with respects to natural sources and sinks. According to the Scientific Assessment of Ozone Depletion completed in 2010, methyl bromide has between 62.1 to $157.8 \mathrm{Gg} / \mathrm{yr}$ in known sources and between 127.6 to $159.6 \mathrm{Gg} / \mathrm{yr}$ in known sinks (Montzka and Reimann 2010) (Table 1.2). This presents a deficit of 65.5 to a deficit of $1.8 \mathrm{Gg} / \mathrm{yr}$ in missing sources from the global budget of methyl bromide in 2010. Even though the uncertainty is large, these numbers show that strides have been taken in recent years to further clarify the atmospheric budget for methyl halides when compared to earlier data. For example, in the Scientific Assessment of Ozone Depletion in 2006, the global budget for methyl bromide was out of balance by $53 \mathrm{Gg} / \mathrm{yr}$ with known sources falling below the amount of 
known sinks (Clerbaux and Cunnold 2007). However, in a study conducted by the World Meteorological Organization in 2003, the methyl bromide budget was unbalanced by $45 \mathrm{Gg} / \mathrm{yr}$, again with sources being outnumbered by sinks (Warwick et al. 2006). These data from 2003, 2006, and 2010 clearly show the uncertainty in the methyl bromide budget. The uncertainty in the methyl chloride budget is also just as apparent when literature is reviewed. Previous studies have mentioned that the methyl chloride budget is more uncertain than the methyl bromide budget with only 50-67\% of known methyl chloride sources being accounted for (Butler 2000; Redeker et al. 2002a). In contrast, scientific assessments released in 2007 and 2010 have shown that sources of methyl chloride range from 1,759.4-13,688.9 Gg/yr with sinks ranging from 3,566-6,515 Gg/yr (Table 1.1) (Keppler et al. 2005; Clerbaux and Cunnold 2007; Montzka and Reimann 2010). Whereas, three-dimensional modeling (a mathematical representation of a threedimensional surface using computer software) has provided estimates that show sinks and sources are more or less balanced for methyl chloride (Lee-Taylor et al. 2000; Yoshida et al. 2004; Clerbaux and Cunnold 2007). Lee-Taylor used a three-dimensional model, IMAGES which is driven on variables ranging from monthly average winds to photodissociation rates to additional environmental factors (2000). Yoshida et al., in contrast, used a model called GEOS-CHEM which is also a global chemical transport model of tropospheric chemistry which is driven by assimilated meteorological data from the Goddard Earth Observing System (GEOS) (2004).

As previously mentioned, methyl halides can be produced by enzyme mediated methyl transferase reactions (Manley 2002; White et al. 2005; Manley et al. 2006). 
However, the exact mechanisms involved in these reactions are currently poorly understood. In definition alone, methyl halide transferase means that an enzyme's primary role is to transfer a methyl group $\left(\mathrm{CH}_{3}\right)$ to a halogen (Redeker et al. 2004a). According to Attieh et al. (1995), the following reaction is responsible for the transfer of a methyl group from $S$-adenosyl- $L$-methionine (AdoMet) to a halide ( $\mathrm{X}^{-}$):

$$
\mathrm{X}^{-}+\text {AdoMet } \rightarrow \mathrm{CH}_{3} \mathrm{X}+\operatorname{AdoHcy}(S \text {-adenosyl-L-homocysteine). }
$$

In a study conducted by Wuosmaa et al. (1990), they found that methyl transfersase produced the following rates of methyl halides emissions in Endocladia muricata, a type of red marine algae: 8 pmol liter ${ }^{-1} \min ^{-1}$ of methyl chloride and $16 \mathrm{pmol}^{-1 \text { iter }}{ }^{-1} \min ^{-1}$ of methyl bromide. In addition to being found in marine algae, previous studies have also found methyl transferase activity in several fungi and halophytic plants (Wuosmaa et al. 1990; Attieh et al. 1995; Saini et al. 1995; Ni et al. 1999).

Methyl halide emissions are most prevalent in subtropical and tropical climates due to increased temperatures and biological activity found in these regions (Butler 2000; Rhew et al. 2000; Yokouchi et al. 2000). One study found that latitudes in the northern hemisphere between $0^{\circ}$ and $35^{\circ}$ had the greatest annual coastal emissions for methyl chloride and methyl bromide with $0.7 \mathrm{Gg} / \mathrm{yr}$ and $0.02 \mathrm{Gg} /$ year, respectively (Hu et al. 2010). Coastal wetlands such as the Florida Everglades, U.S.A., are one location where methyl halide emissions have been proposed to be elevated due to the increased levels of primary production and ionic halogens. The Everglades make an ideal study location due to the subtropical climate and ample sunlight which drive primary production (Gaiser et al. 2011; Hagerthey et al. 2011) that in turn generates methyl halides. In fact, the 
Everglades have some of the highest primary production rates of any wetland (Goldsborough and Robinson 1996; Ewe et al. 2006; The Comprehensive Everglades Restoration Plan (CERP) 2010). It is also one of the largest wetlands in the world and covers an area around $5000 \mathrm{~km}^{2}$ (McCormick et al. 1998; Noe et al. 2001; La Hee and Gaiser 2012).

The Florida Everglades also provides a unique study environment due to salt water intrusions which occur during storm or low marsh water level-high tide events. Previous studies have documented methyl halide emissions in salt marshes due primarily to the increased levels of chloride and bromide ions in seawater (Rhew et al. 2000; Rhew et al. 2002; Drewer et al. 2006; Manley et al. 2006: Manley et al. 2007; Blei et al. 2010; Montzka and Reimann 2010). According to Butler 2000, salt marshes make up less than $0.1 \%$ of the global surface area, but they could be producing $10 \%$ of the global budget for methyl chloride and methyl bromide. As global climate changes, the amount of land exposed to salt water intrusions could increase dramatically due to rising sea levels. It has been proposed that sea levels could rise by 1 to $2 \mathrm{~m}$ in southern Florida by 2100 (Allison et al. 2009; Saha et al. 2011). This shows why studying salt water intrusions in a freshwater environment is important when clarifying methyl halide emissions within the Florida Everglades and other similar wetlands.

Calcareous periphyton mats are a collection of benthic algae, microbes, fungi, and detritus that are often attached to benthic, submerged, or floating surfaces (Noe et al. 2001; Gaiser et al. 2011; La Hee and Gaiser 2012). They are a ubiquitous feature within the Florida Everglades and are considered to be a dominant portion of the standing crop 
within this ecosystem (Scheidt et al.2000; Donar et al. 2004; Gaiser et al. 2011; Hagerthey et al. 2011). These mats are also characterized by growing in areas with calcium carbonate as a substrate (Noe et al. 2001). Periphyton mats are also an important component within the Everglades by helping to remove calcium carbonate from the water and depositing it as marl soils, increasing oxygen levels within the water which benefits aquatic organisms, decreasing phosphorus levels, and serving as a base in food webs (Scheidt et al. 2000; Brown and Wright 2009; La Hee and Gaiser 2012). Previous studies have shown that algae, a major component of periphyton (Attieh et al. 1995; Saini et al. 1995; Paul and Pohnert 2011), and fungi (Redeker et al. 2004b) are sources of methyl halide emissions. However, periphyton mats as a whole have not previously been studied as a potential source of methyl halide emissions. 


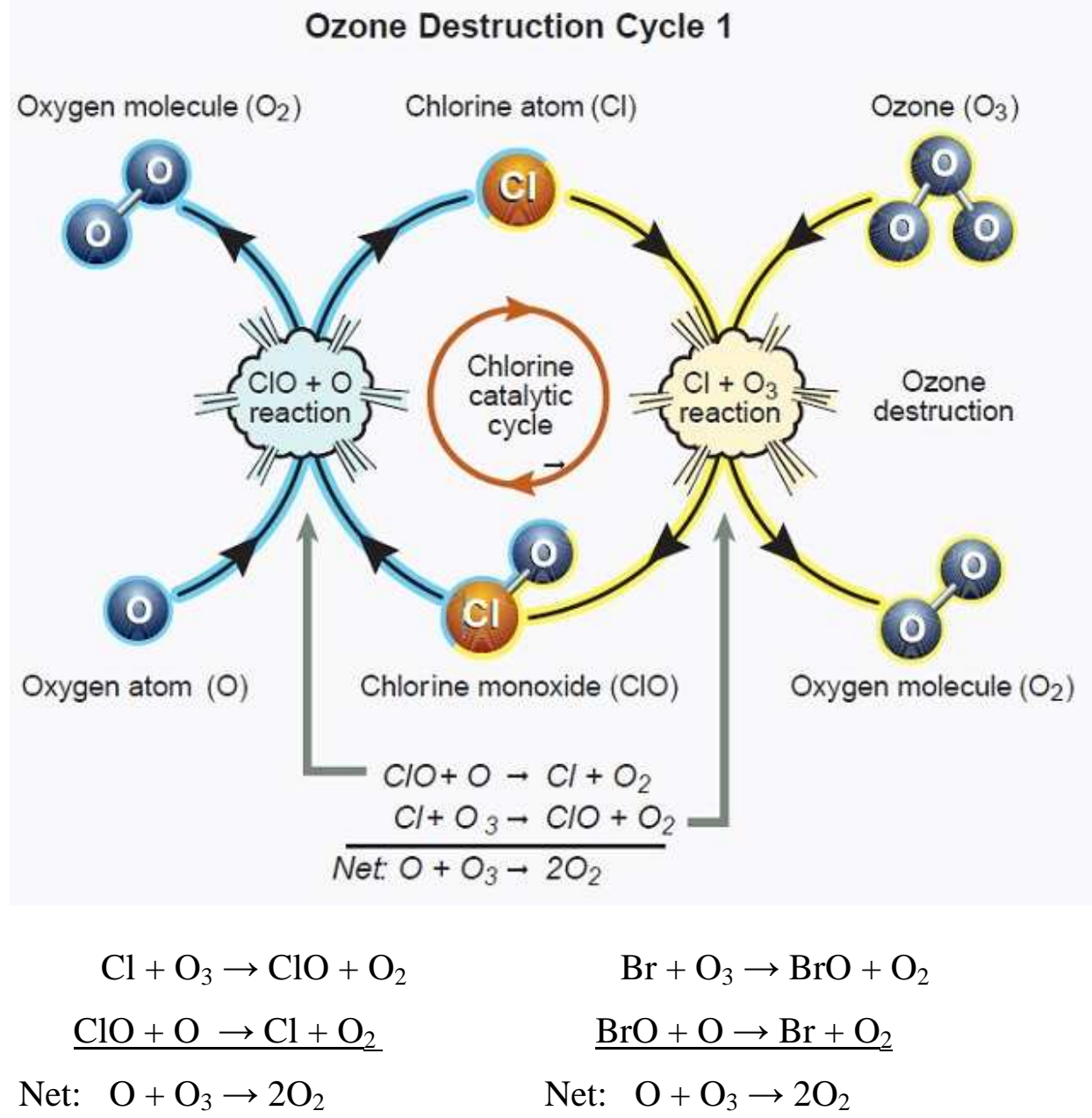

Figure 1.1: Diagram and reaction pathways for ozone destruction cycles (Fahey 2007; Blei 2010). 
Table 1.1: Estimated source and sink strengths $(\mathrm{Gg} / \mathrm{yr})$ for methyl chloride $\left(\mathrm{CH}_{3} \mathrm{Cl}\right)$.

\begin{tabular}{|c|c|}
\hline Sources & \\
\hline Tropical/subtropical vegetation & $820-8200^{a, b}$ \\
\hline Tropical senescent or dead leaves & $30-2500^{a, b}$ \\
\hline Biomass burning & $325-1125^{\mathrm{a}}$ \\
\hline Oceans & $400-600^{\mathrm{a}, \mathrm{b}}$ \\
\hline Fungi & $43-470^{a}$ \\
\hline Salt marshes & $50-440^{\mathrm{a}, \mathrm{b}}$ \\
\hline Wetlands & $48^{\mathrm{a}}$ \\
\hline Mangroves & $11^{\mathrm{b}}$ \\
\hline Rice Paddies & $2.4-4.9^{\mathrm{a}}$ \\
\hline Other anthropogenic sources & $30-290^{\mathrm{a}}$ \\
\hline Subtotal & 1759.4-13688.9 \\
\hline \multicolumn{2}{|l|}{ Sinks } \\
\hline Reaction with $\mathrm{OH}^{-}$ & $3180-4100^{\mathrm{a}, \mathrm{b}}$ \\
\hline Loss to the stratosphere & $100-300^{a, b}$ \\
\hline Marine boundary layer $\mathrm{Cl}^{-}$reaction & $93-370^{\mathrm{a}, \mathrm{b}}$ \\
\hline Microbial soil degradation & $100-1600^{a, b}$ \\
\hline Loss to polar ocean waters & $93-145^{\mathrm{a}, \mathrm{b}}$ \\
\hline SubTotal & $3566-6515$ \\
\hline Total (Sources-Sinks) & -1806.6 to 7173.9 \\
\hline
\end{tabular}
a. Clerbaux and Cunnold 2007
b. Montzka and Reimann 2010 
Table 1.2: Estimated source and sink strengths $(\mathrm{Gg} / \mathrm{yr})$ for methyl bromide $\left(\mathrm{CH}_{3} \mathrm{Br}\right)$.

\begin{tabular}{lr}
\hline Sources & \\
\hline Ocean & $34.0-49.0^{\mathrm{a}}$ \\
Fumigation & $11.7-17.1^{\mathrm{a}}$ \\
Biomass burning & $10.0-40.0^{\mathrm{a}}$ \\
Temperate peatlands & $-0.1-1.3^{\mathrm{a}}$ \\
Coastal salt marshes & $0.2-29^{\mathrm{a}}$ \\
Rice paddies & $0.1-1.7^{\mathrm{a}}$ \\
Mangroves & $1.2-1.3^{\mathrm{a}}$ \\
Rapeseed & $4.0-6.1^{\mathrm{a}}$ \\
Fungi & $1.0-5.7^{\mathrm{a}}$ \\
Shrublands & $0.0-1.0^{\mathrm{a}}$ \\
Leaded gasoline & $0-5.6^{\mathrm{a}}$ \\
Subtotal & $\mathbf{6 2 . 1}$ to 157.8 \\
\hline Sinks & $63.6^{\mathrm{a}}$ \\
\hline OH ${ }^{-}$and photolysis & $19.0-44.0^{\mathrm{a}}$ \\
Oceans & $\mathbf{1 2 7 . 6 - 1 5 9 . 6}$ \\
Soils & $\mathbf{- 6 5 . 5}$ to -1.8 \\
SubTotal & $45.0-52.0^{\mathrm{a}}$ \\
\hline Total (Sources-Sinks) &
\end{tabular}

*Notes

a. Montzka and Reimann 2010 


\section{Chapter 2}

\section{Materials and methods}

\section{Study sites and periphyton sampling}

All periphyton samples were collected during the wet seasonal period from Taylor Slough 2 (TS 2) and Taylor Slough 3 (TS 3), within the boundaries of the Everglades National Park (ENP), Florida, U.S.A. (Figure 2.1). Taylor Slough is the second largest path of moving surface water located on the eastern side of ENP, which ultimately flows south into Florida Bay (Armentano et al. 2006). TS 2 and TS 3 are predominately freshwater marsh sites; however, T3 receives saltwater intrusions occasionally, as evidenced by the presence of red mangroves, Rhizophora mangle (Trexler et al. 2006). In addition, these sites are dominated by emergent vegetation such as Cladium jamaicense (sawgrass) and more importantly an abundance of periphyton. Periphyton samples were initially collected in September 2011 from TS 2 and TS 3 and then again in August 2012 from TS 2 only. All periphyton grab samples were randomly collected and subsequently placed in gallon size Ziploc® bags and coolers. After collection, all samples were shipped back to Portland State University and either immediately placed under refrigeration or placed in previously set up microcosms in a research greenhouse.

\section{Microcosms}

Collected periphyton was randomly placed in $36.2 \mathrm{~cm}$ x $31.1 \mathrm{~cm}$ x $14.3 \mathrm{~cm}(9.5$ liter) polypropylene pans, which contained a 1.5 to $2 \mathrm{~cm}$ base layer of calcium carbonate rocks to simulate the substrate found naturally in the Florida Everglades (Noe et al.2001; Gaiser et al.2011; Hagerthey et al. 2011) (Figure 2.2). All microcosms were placed in a 
research greenhouse with constant temperatures and photoperiods $\left(30^{\circ} \mathrm{C}\right.$ and 14 hour light/10 hour dark cycles). In addition, each pan initially received $10 \mathrm{~cm}$ of artificial marsh water that contained essential trace elements such as sodium bicarbonate $\left(\mathrm{NaHCO}_{3}\right)$, potassium chloride $(\mathrm{KCl})$, magnesium chloride $\left(\mathrm{MgCl}_{2} \cdot 6 \mathrm{H}_{2} \mathrm{O}\right)$, and lastly calcium chloride $\left(\mathrm{CaCl}_{2} 2 \mathrm{H}_{2} \mathrm{O}\right)$. All proportions for the trace elements were made according to methods described in Jones and Amador (1992). After initial filling, all polypropylene pans were refilled twice a week, to restore original water levels, with 18.1 megohms water, which was previously filtered in a Barnstead Nanopure Diamond Lab Water System. This allowed for all concentrations of trace elements to remain constant throughout the duration of the experiments. All periphyton was allowed to become reestablished before use, with a minimum time period of four to six weeks.

Reestablishment occurred when gas bubbles appeared on the surface of the periphyton.

\section{Experimental methods}

Once reestablished, approximately 90 wet weight (w.w.) g of periphyton was randomly collected from one of the microcosms in the research greenhouse. Periphyton was first prepared for each experiment by removing any apparent dead vegetation and/or calcium carbonate rocks, followed by light patting to remove any excess water. Lastly, periphyton was sliced into small pieces using a razor blade and weighted into nine subsamples of either 5 g (w.w.) for experiments run from March 2012 to mid-August 2012 or 10 g (w.w) for experiments conducted from mid-August 2012-March 2013. Subsample size was increased to allow for an increased signal on the chromatographs. Each of the nine subsamples were placed in a $200 \mathrm{~mL}$ quartz tube and filled with 
$\sim 160 \mathrm{~mL}$ of either artificial marsh water $(0 \%$ o) or one of the following salt water concentrations $(0.1,1,5$, or $10 \%$ ) (Figure 2.3$)$. All salt water was made by using artificial marsh water and adding the appropriate amount of sodium chloride $(\mathrm{NaCl})$ and sodium bromide $(\mathrm{NaBr})$ to reach the desired concentration level. Each quartz tube was equipped with a one way stopcock valve and plunger. After the addition of both periphyton and water, each quartz tube was inverted three to four times to allow for mixing of the two components. This was followed by the subsequent removal of any headspace. This was accomplished by holding the quartz tube vertically while pressing the plunger towards the open stopcock valve. Once all headspace was removed the valve was reclosed. All quartz tubes were then placed in a VWR low temperature diurnal illumination incubator (model number 2015), with preset temperature and photoperiods $\left(30^{\circ} \mathrm{C}\right.$ and 12 dark/12 light cycles), and allowed to set for at least 24 hours before testing. After placing the quartz tubes in the incubator, three $55 \mathrm{~mL}$ samples of that experiment's original water $(0,0.1,1,5$, or $10 \%$ o were analyzed for a time zero reading using a gas chromatograph coupled with an electron capture detector (GC-ECD) to determine the base level concentrations of $\mathrm{CH}_{3} \mathrm{Cl}$ and $\mathrm{CH}_{3} \mathrm{Br}$ in each sample. After 24 hours, one quartz tube was removed and all of the sample water was transferred to another quartz tube with a one-way stopcock valve and plunger. Over the course of a three and half to four hour time period, three samples ranging from $45-55 \mathrm{~mL}$ were obtained from the second quartz tube (all samples were later normalized to per $\mathrm{L}$ ) and analyzed using the GC-ECD. This procedure was replicated for two additional quartz tubes, with each containing three additional samples ( $\mathrm{n}=9$ for 24 hour value). This was repeated again at 48 and 72 hours 
( $\mathrm{n}=9$ for each sampling time). All periphyton was discarded once the simulated marsh water was transferred into an empty quartz tube.

\section{Gas chromatograph with electron capture detector (GC-ECD)}

A gas chromatograph (GC) (Hewlett Packard series II 5890) coupled with an electron capture detector (ECD) and a pre-concentration system was used to analyze all methyl halide concentrations. This system was modified from a system described by Regina Huset (Huset 2007). A schematic diagram of the system is shown in Figure 2.4. All methyl chloride and methyl bromide peak areas were analyzed using the Agilent EZChrom SI (version 3.2) software.

\section{Modifications to the pre-concentration system}

Several modifications were made to the pre-concentration system for methyl halide analysis. This system remained automated; however, the automated trap heating and cooling system was replaced by a manual system. A $665 \mathrm{~mL}$ Pope dewar filled with cooled laboratory grade ethanol $\left(\sim^{-} 43^{\circ} \mathrm{C}\right)$, cooled to the desired temperature by pure liquid nitrogen, was used for the cold bath and a second Pope dewar with boiling water $\left(\sim 100^{\circ} \mathrm{C}\right)$ was used for the hot bath. Another modification consisted of attaching a condenser to the stripping chamber to remove extra water from exiting sparged gases (Figure 2.4). This was done by submerging the condenser in either an ice water or cooled ethanol bath $\left(\sim 0^{\circ} \mathrm{C}\right)$. Modifications were also made to port 2 in valve 8 and ports 2 and 6 in valve 9. Port 2 in valve 8 does not attach to a second column within the GC but instead was attached to the helium tank (tank 1) that provided the carrier gas for the GC trap. Port 2 in valve 9 was capped off, while port 6 was rerouted to valve 8 to make a 
continuous loop between valves 8 and 9. Lastly, the desiccant tube found between valve 4 and 7 was filled with half magnesium perchlorate and a 50/50 mixture of glass beads and magnesium perchlorate.

\section{Modifications to the GC-ECD}

Modifications were made to gas chromatograph as well. For one, a Supel- $\mathrm{Q}^{\mathrm{TM}}$ Plot with guards and a fused silica capillary column (30m with a $0.53 \mathrm{~mm}$ ID) was used for the GC column. A mass flow controller was also installed to control the flow of helium to the GC (tank 1) in both operational and standby mode, the nitrogen and oxygen makeup gas to the ECD during operational mode, and nitrogen (tank 2) to the ECD during standby mode (Figure 2.4). Ultra-pure helium was used as the carrier gas for the GC and pre-concentration system due to its ability to produce cleaner separations between peaks of targeted compounds.

\section{Moisture and oxygen purifier/traps}

Modifications were also made to moisture traps for all carrier and makeup gas lines. S-traps containing molecular sieves were installed in the helium (tank 1) line supplying the $\mathrm{GC}, \mathrm{N}_{2} / \mathrm{O}_{2}$ makeup gas line supplying the ECD, and the nitrogen (tank 4) line which flushed out the water trap when the GC-ECD was in standby mode. Gas Dry Purifiers (made by Chromatography Research Supplies) for moisture and dust were installed in both of the helium gas lines (Figure 2.4). ZPure ${ }^{\mathrm{TM}}$ glass water and hydrocarbon purifiers (made by Chromatography Research Supplies) were added to helium line (tank 1) supplying the GC and to the nitrogen (tank 2) line that supplies the ECD in standby mode. OxiClear ${ }^{\mathrm{TM}}$ Gas Purifiers, which absorbs oxygen in the carrier 
gas lines, were added to each of the gas lines originating from the helium tanks. In addition to the above purifiers and traps, an additional water trap was installed after the Gas Dry Purifier and Oxiclear ${ }^{\mathrm{TM}}$ oxygen filter. This trap was subsequently submerged in a pure liquid nitrogen bath during operational mode. When the GC was in standby mode this trap was heated to $\sim 200^{\circ} \mathrm{C}$ with a continuous light flow of helium to flush out any accumulated impurities that subsequently vented out.

\section{Calibration curves}

Calibration curves were run every four to six weeks to allow for the accurate determination of the amount of methyl chloride and methyl bromide. These curves consisted of at least three replicates for three different concentrations. The concentrations used included a blank using the $100 \mathrm{~mL}$ loop plus the $14 \mathrm{~mL}$ loop, the $14 \mathrm{~mL}$ loop using tank number 39729 ( 8 ppb methyl chloride and 0.355 ppb methyl bromide), and lastly the $100 \mathrm{~mL}$ loop plus the $14 \mathrm{~mL}$ loop, which also used tank 39729. All blanks and standards were injected into the GC's pre-concentration system for two minutes prior to starting EZChrom software.

Average percent error for methyl chloride in blanks was approximately 3\%; whereas, methyl bromide was not present in any of the blanks. The $14 \mathrm{~mL}$ loop had percent error averages of $0.9 \%$ and $5.2 \%$, respectively, while the $100 \mathrm{~mL}$ plus $14 \mathrm{~mL}$ loop saw averages of $1.1 \%$ and $1.2 \%$, respectively.

\section{Water samples}

All water samples were injected into a glass stripping chamber attached to the front of the pre-concentration system. Peak areas of methyl chloride and methyl bromide 
were then inputted into the equation of the lines found during the most recent calibration curve to determine the number of moles for each compound.

\section{Data analysis}

Normalization of all methyl halide concentrations was performed to allow for easier comparison between the data points, due to differing conditions within quartz tubes. All methyl chloride and methyl bromide data was converted to picomolar (pM) per w.w. gram of periphyton per hour. All data was checked for normality and equal variance using SigmaPlot and R software. Pearson correlation coefficients were used to assess a possible relationship between salinity and methyl chloride and methyl bromide production rates using SigmaPlot software. Alpha level was set at 0.05 for all statistical analyses. 


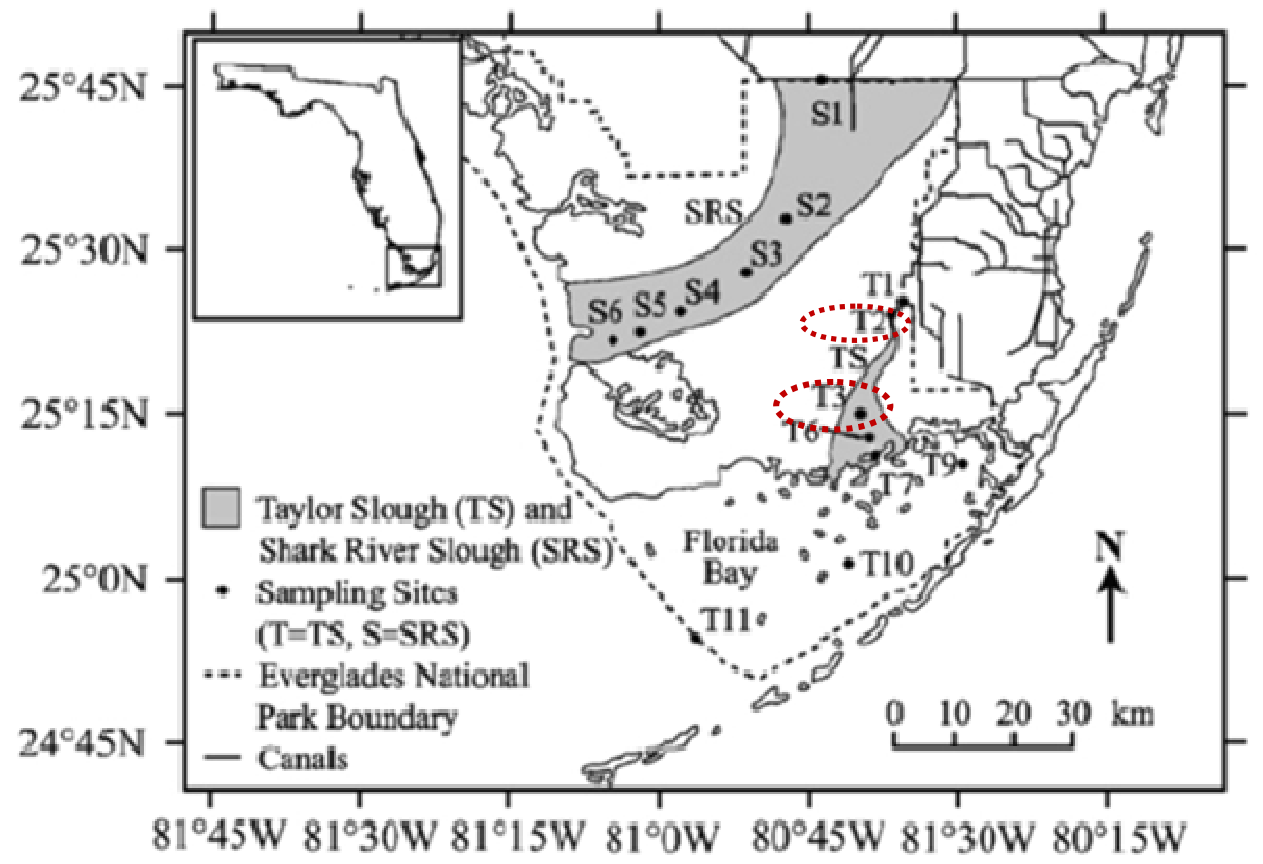

Figure 2.1: Map of the Florida Everglades, U.S.A. with periphyton sampling sites (TS 2 and 3) circled (Maie et al. 2007).

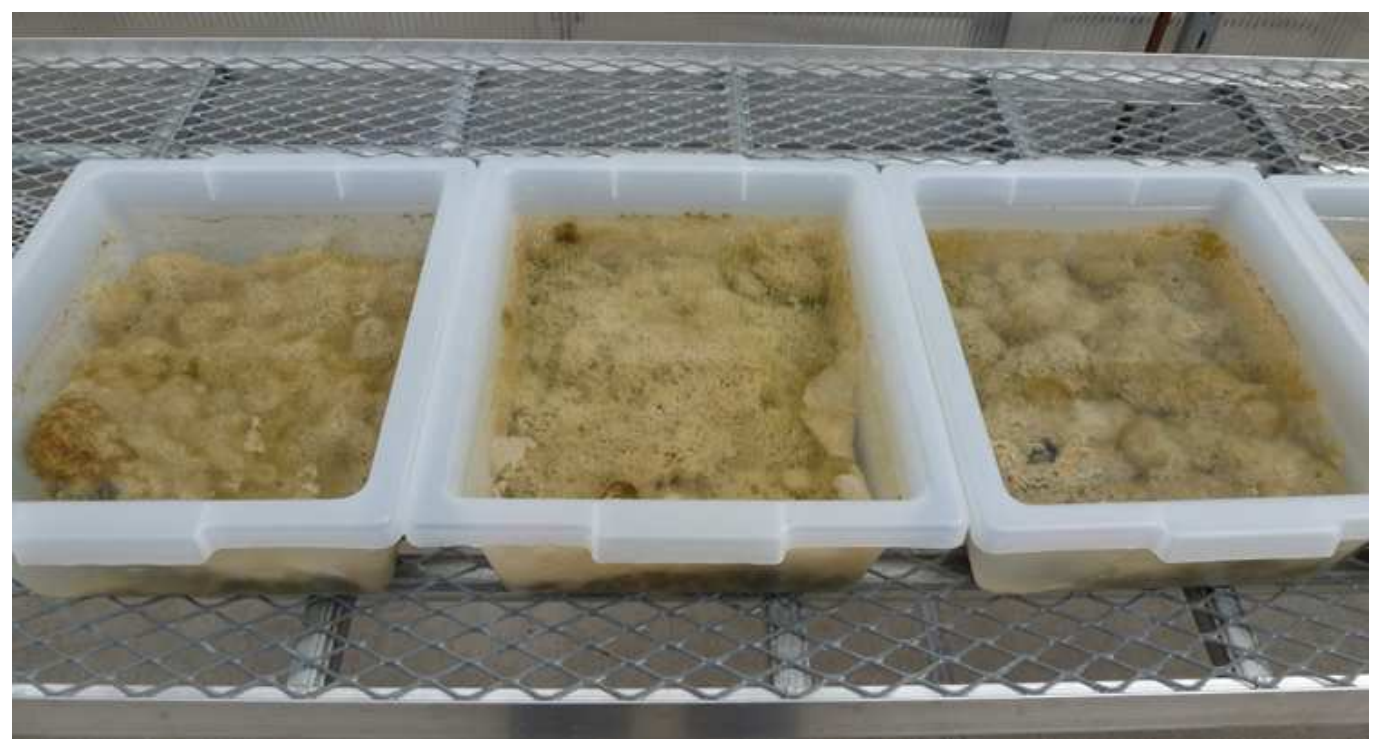

Figure 2.2: Periphyton microcosms in the research greenhouse. 


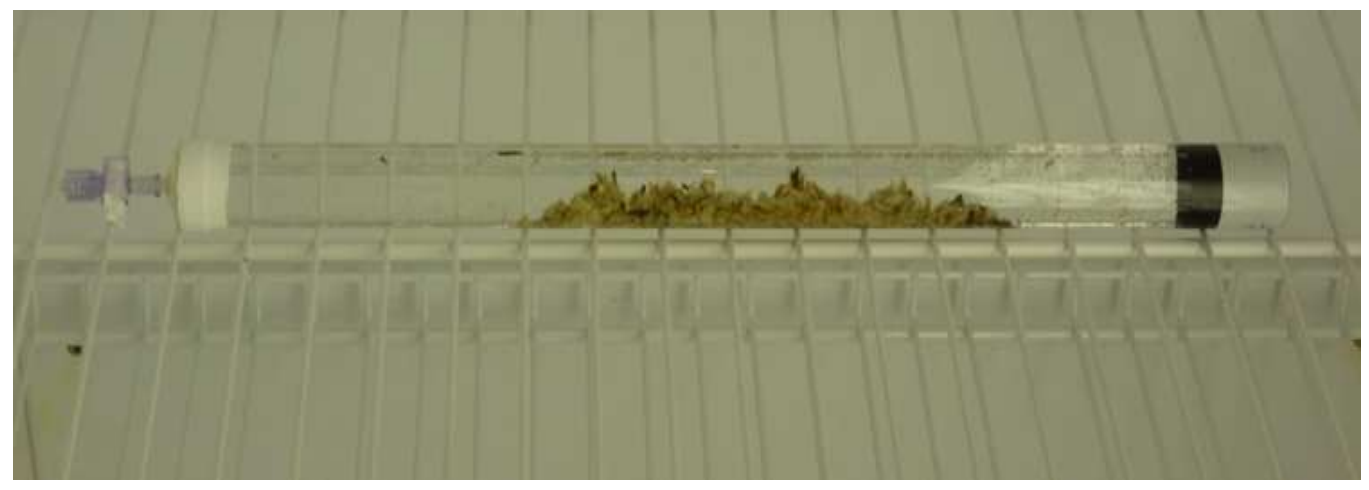

Figure 2.3: Quartz tube with periphyton and attached stopcock valve. 


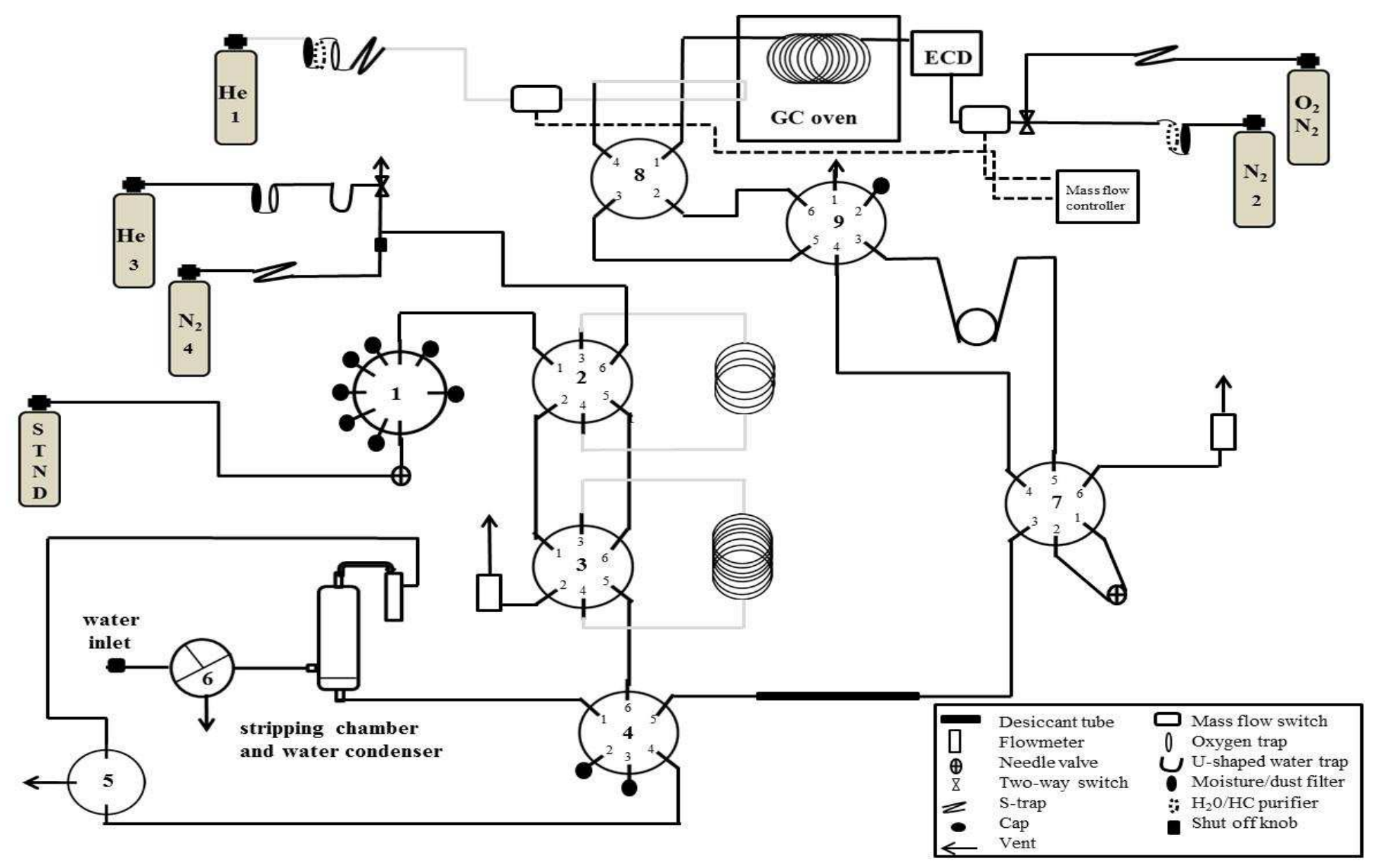

Figure 2.4: Schematic diagram for GC-ECD for methyl halide analysis. 


\section{Chapter 3}

\section{Results}

\section{Methyl chloride}

At the conclusion of this study, calcereous periphyton mats were found to be a producer of methyl chloride in all freshwater $(0 \%)$ trials and sampling times. Production rates ranged from 0.077 to $0.109 \mathrm{pM} \mathrm{g}^{-1} \mathrm{hr}^{-1}$ after 24 hours, 0.027 to $0.073 \mathrm{pM} \mathrm{g}^{-1} \mathrm{hr}^{-1}$ after 48 hours, and 0.034 to $0.047 \mathrm{pM} \mathrm{g}^{-1} \mathrm{hr}^{-1}$ after 72 hours (Table 3.1). A significant reduction in production rates was found between 24 and 48 hours $(t=2.961, \mathrm{df}=16$, $\mathrm{p}$ value $=0.0092$ ); however, the additional drop in production rates between 48 and 72 hours was not significantly different $(\mathrm{t}=0.3875, \mathrm{df}=13, \mathrm{p}$-value $=0.7046)$ (Figure 3.1 and Table $3.1)$.

Results from saltwater treatments also showed methyl chloride production at all concentrations and times, except for the 1\%o experiment ran in March 2012 after 24 hours. Production values ranged from 0.021 to $0.198 \mathrm{pM} \mathrm{g}^{-1} \mathrm{hr}^{-1}$ after 24 hours, 0.009 to $0.124 \mathrm{pM} \mathrm{g}^{-1} \mathrm{hr}^{-1}$ after 48 hours, and 0.020 to $0.098 \mathrm{pM} \mathrm{g}^{-1} \mathrm{hr}^{-1}$ after 72 hours for the $0.1 \%$ o salt water treatment (Figure 3.1 and Table 3.2). The $1 \%$ o salt water treatment found rates from -0.005 to $0.342 \mathrm{pM} \mathrm{g}^{-1} \mathrm{hr}^{-1}$ after 24 hours, 0.026 to $0.188 \mathrm{pM} \mathrm{g}^{-1} \mathrm{hr}^{-1}$ after 48 hours, and 0.017 to $0.130 \mathrm{pM} \mathrm{g}^{-1} \mathrm{hr}^{-1}$ after 72 hours (Figure 3.1 and Table 3.3).

Production rates for the $5 \%$ saltwater treatment ranged from 0.288 to $0.364 \mathrm{pM} \mathrm{g}^{-1} \mathrm{hr}^{-1}$ after 24 hours, 0.162 to $0.270 \mathrm{pM} \mathrm{g}^{-1} \mathrm{hr}^{-1}$ after 48 hours, and 0.168 to 0.221 $\mathrm{pM} \mathrm{g}^{-1} \mathrm{hr}^{-1}$ after 72 hours (Figure 3.1 and Table 3.4). The last saltwater treatment of $10 \%$ 
(brackish water) found rates from 0.442 to $0.624 \mathrm{pM} \mathrm{g}^{-1} \mathrm{hr}^{-1}$ after 24 hours, 0.281 to $0.549 \mathrm{pM} \mathrm{g}^{-1} \mathrm{hr}^{-1}$ after 48 hours, and 0.181 to $0.387 \mathrm{pM} \mathrm{g}^{-1} \mathrm{hr}^{-1}$ after 72 hours (Figure 3.1 and Table 3.5). During the month of October 2012, one experiment from each saltwater treatment was performed except for the 5\%o treatment, which was run during February 2013 (Figure 3.2).

Production rates at 24 hours for the 0.1 and $1 \%$ salt water treatments were not statistically different from the 24 hour freshwater $(0 \%$ ) production rates $(\mathrm{t}=-0.0217$, $\mathrm{df}=10.945, \mathrm{p}$-value $=0.9831 ; \mathrm{t}=-0.457, \mathrm{df}=8.587, \mathrm{p}=$ value $=0.659$, respectively $).$ However, the 24 hour production rates were significantly different from the freshwater rates in the 5 and $10 \%$ o saltwater treatments $(\mathrm{t}=-11.762, \mathrm{df}=16, \mathrm{p}-\mathrm{value}=3.069 \mathrm{e}-09 ; \mathrm{t}=-9.501, \mathrm{df}=8.094$, $\mathrm{p}$-value $=1.14 \mathrm{e}-5$, respectively). Overall, there was significant positive relationship between methyl chloride production and salinity after 24 hours $\left(\mathrm{p}<0.001, \mathrm{R}^{2}=0.7125\right.$, $\mathrm{n}=44$ ) (Figure 3.3). Due to the significant reduction of production rates after 24 hours, the 0 to 24 hour production rates were viewed as the most appropriate rates to use for the relationship analysis. 
Table 3.1: Average values for $0 \%$ (freshwater) experiments for methyl chloride $\left(\mathrm{CH}_{3} \mathrm{Cl}\right)$ concentrations and production over time for all trials. Standard deviations are noted.

\begin{tabular}{|c|c|c|c|c|c|c|}
\hline $\begin{array}{c}\text { Experiment Date } \\
\text { (month/year) }\end{array}$ & $\begin{array}{l}\text { Time } \\
\text { (hrs) }\end{array}$ & $\mathbf{n}$ & 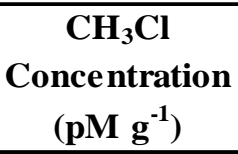 & $\begin{array}{c}\mathrm{CH}_{3} \mathrm{Cl} \\
\text { Production } \\
\left(\mathrm{pM} \mathrm{g} \mathrm{g}^{-1}\right) \\
\end{array}$ & $\begin{array}{c}\mathrm{CH}_{3} \mathrm{Cl} \\
\text { Production } \\
\left(\mathrm{pM} \mathrm{g}^{-1} \mathbf{h r}^{-1}\right)\end{array}$ & $\begin{array}{c}\text { STD } \\
\left(\mathrm{pM} \mathrm{g}^{-1} \mathbf{h r}^{-1}\right)\end{array}$ \\
\hline \multirow[t]{4}{*}{ October 2012} & 0 & 3 & 5.364 & 0.000 & 0.000 & 0.000 \\
\hline & 24 & 9 & 7.467 & 2.103 & 0.088 & 0.039 \\
\hline & 48 & 9 & 8.878 & 3.514 & 0.073 & 0.011 \\
\hline & 72 & 8 & 8.765 & 3.402 & 0.047 & 0.013 \\
\hline \multirow[t]{4}{*}{ January 2013} & 0 & 3 & 4.702 & 0.000 & 0.000 & 0.000 \\
\hline & 24 & 9 & 6.540 & 1.838 & 0.077 & 0.031 \\
\hline & 48 & 8 & 6.013 & 1.311 & 0.027 & 0.030 \\
\hline & 72 & 0 & & & & \\
\hline \multirow[t]{4}{*}{ February 2013} & 0 & 3 & 5.443 & 0.000 & 0.000 & 0.000 \\
\hline & 24 & 7 & 8.069 & 2.626 & 0.109 & 0.040 \\
\hline & 48 & 9 & 7.316 & 1.873 & 0.039 & 0.016 \\
\hline & 72 & 9 & 7.860 & 2.417 & 0.034 & 0.023 \\
\hline
\end{tabular}

Table 3.2: Average values for $0.1 \%$ oxperiments for methyl chloride $\left(\mathrm{CH}_{3} \mathrm{Cl}\right)$ concentrations and production over time for all trials. Standard deviations are noted.

\begin{tabular}{|c|c|c|c|c|c|c|}
\hline $\begin{array}{c}\text { Experiment Date } \\
\text { (month/year) }\end{array}$ & $\begin{array}{l}\text { Time } \\
\text { (hrs) }\end{array}$ & $\mathbf{n}$ & $\begin{array}{c}\mathrm{CH}_{3} \mathrm{Cl} \\
\text { Concentration } \\
\left(\mathrm{pM} \mathrm{g}^{-1}\right)\end{array}$ & $\begin{array}{c}\mathrm{CH}_{3} \mathrm{Cl} \\
\text { Production } \\
\left(\mathrm{pM} \mathrm{g}^{-1}\right)\end{array}$ & $\begin{array}{c}\mathrm{CH}_{3} \mathrm{Cl} \\
\text { Production } \\
\left(\mathrm{pM} \mathrm{g}^{-1} \mathrm{hr}^{-1}\right)\end{array}$ & 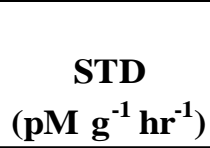 \\
\hline \multirow[t]{4}{*}{ October 2012} & 0 & 3 & 6.318 & 0.000 & 0.000 & 0.000 \\
\hline & 24 & 9 & 11.061 & 4.744 & 0.198 & 0.035 \\
\hline & 48 & 9 & 12.285 & 5.967 & 0.124 & 0.019 \\
\hline & 72 & 9 & 13.395 & 7.077 & 0.098 & 0.038 \\
\hline \multirow[t]{4}{*}{ December 2012} & 0 & 3 & 6.184 & 0.000 & 0.000 & 0.000 \\
\hline & 24 & 9 & 7.609 & 1.425 & 0.059 & 0.018 \\
\hline & 48 & 9 & 6.624 & 0.441 & 0.009 & 0.016 \\
\hline & 72 & 9 & 10.779 & 4.596 & 0.064 & 0.032 \\
\hline \multirow[t]{4}{*}{ January 2013} & 0 & 3 & 5.241 & 0.000 & 0.000 & 0.000 \\
\hline & 24 & 9 & 5.751 & 0.509 & 0.021 & 0.031 \\
\hline & 48 & 9 & 6.664 & 1.423 & 0.030 & 0.014 \\
\hline & 72 & 9 & 6.700 & 1.459 & 0.020 & 0.012 \\
\hline
\end{tabular}


Table 3.3: Average values for $1 \%$ o experiments for methyl chloride $\left(\mathrm{CH}_{3} \mathrm{Cl}\right)$ concentrations and production over time for all trials. Standard deviations are noted.

\begin{tabular}{|c|c|c|c|c|c|c|}
\hline $\begin{array}{c}\text { Experiment Date } \\
\text { (month/year) }\end{array}$ & $\begin{array}{l}\text { Time } \\
\text { (hrs) }\end{array}$ & $\mathbf{n}$ & 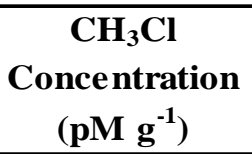 & $\begin{array}{c}\mathrm{CH}_{3} \mathrm{Cl} \\
\text { Production } \\
\left(\mathrm{pM} \mathrm{g} \mathrm{g}^{-1}\right)\end{array}$ & $\begin{array}{c}\mathrm{CH}_{3} \mathrm{Cl} \\
\text { Production } \\
\left(\mathrm{pM} \mathrm{g}^{-1} \mathrm{hr}^{-1}\right)\end{array}$ & $\begin{array}{c}\text { STD } \\
\left(\mathrm{pM} \mathrm{g}^{-1} \mathbf{h r}^{-1}\right)\end{array}$ \\
\hline \multirow[t]{4}{*}{ July 2012} & 0 & 3 & 8.126 & 0.000 & 0.000 & 0.000 \\
\hline & 24 & 9 & 8.810 & 3.420 & 0.029 & 0.048 \\
\hline & 48 & 9 & 9.358 & 6.158 & 0.026 & 0.019 \\
\hline & 72 & 9 & 9.326 & 5.996 & 0.017 & 0.027 \\
\hline \multirow[t]{4}{*}{ March 2012} & 0 & 3 & 15.684 & 0.000 & 0.000 & 0.000 \\
\hline & 24 & 9 & 15.573 & -0.552 & -0.005 & 0.136 \\
\hline & 48 & 9 & 20.723 & 25.198 & 0.105 & 0.023 \\
\hline & 72 & 9 & 21.658 & 29.873 & 0.083 & 0.084 \\
\hline \multirow[t]{4}{*}{ October 2012} & 0 & 3 & 6.672 & 0.000 & 0.000 & 0.000 \\
\hline & 24 & 9 & 14.876 & 82.039 & 0.342 & 0.068 \\
\hline & 48 & 9 & 15.712 & 90.392 & 0.188 & 0.024 \\
\hline & 72 & 9 & 16.011 & 93.382 & 0.130 & 0.036 \\
\hline
\end{tabular}

Table 3.4: Average values for 5\%o experiments for methyl chloride $\left(\mathrm{CH}_{3} \mathrm{Cl}\right)$ concentrations and production over time for all trials. Standard deviations are noted.

\begin{tabular}{|c|c|c|c|c|c|c|}
\hline $\begin{array}{c}\text { Experiment Date } \\
\text { (month/year) }\end{array}$ & $\begin{array}{l}\text { Time } \\
(\mathrm{hrs})\end{array}$ & $\mathbf{n}$ & 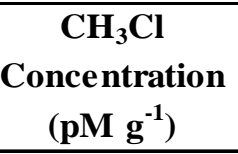 & $\begin{array}{c}\mathrm{CH}_{3} \mathrm{Cl} \\
\text { Production } \\
\left(\mathrm{pM} \mathrm{g}^{-1}\right) \\
\end{array}$ & $\begin{array}{c}\mathrm{CH}_{3} \mathrm{Cl} \\
\text { Production } \\
\left(\mathrm{pM} \mathrm{g}^{-1} \mathbf{h r}^{-1}\right)\end{array}$ & $\begin{array}{c}\text { STD } \\
\left(\mathbf{p M ~ g}^{-1} h \mathbf{r}^{-1}\right)\end{array}$ \\
\hline \multirow[t]{4}{*}{ February 18, 2013} & 0 & 3 & 5.461 & 0.000 & 0.000 & 0.000 \\
\hline & 24 & 9 & 12.361 & 6.901 & 0.288 & 0.053 \\
\hline & 48 & 9 & 13.216 & 7.756 & 0.162 & 0.028 \\
\hline & 72 & 9 & 17.531 & 12.070 & 0.168 & 0.031 \\
\hline \multirow[t]{4}{*}{ February 26, 2013} & 0 & 3 & 4.979 & 0.000 & 0.000 & 0.000 \\
\hline & 24 & 9 & 13.711 & 8.733 & 0.364 & 0.046 \\
\hline & 48 & 9 & 17.950 & 12.971 & 0.270 & 0.064 \\
\hline & 72 & 9 & 20.901 & 15.922 & 0.221 & 0.030 \\
\hline \multirow{4}{*}{ March 2013} & 0 & 3 & 4.975 & 0.000 & 0.000 & 0.000 \\
\hline & 24 & 9 & 13.140 & 8.165 & 0.340 & 0.029 \\
\hline & 48 & 9 & 16.301 & 11.326 & 0.236 & 0.062 \\
\hline & 72 & 9 & 18.647 & 13.671 & 0.190 & 0.010 \\
\hline
\end{tabular}


Table 3.5: Average values for $10 \%$ experiments for methyl chloride $\left(\mathrm{CH}_{3} \mathrm{Cl}\right)$ concentrations and production over time for all trials. Standard deviations are noted.

\begin{tabular}{|c|c|c|c|c|c|c|}
\hline $\begin{array}{c}\text { Experiment Date } \\
\text { (month/year) }\end{array}$ & $\begin{array}{l}\text { Time } \\
\text { (hrs) }\end{array}$ & $\mathbf{n}$ & 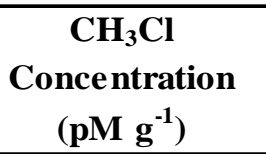 & $\begin{array}{c}\mathrm{CH}_{3} \mathrm{Cl} \\
\text { Production } \\
\left(\mathrm{pM} \mathrm{g}^{-1}\right)\end{array}$ & $\begin{array}{c}\mathrm{CH}_{3} \mathrm{Cl} \\
\text { Production } \\
\left(\mathrm{pM} \mathrm{g}^{-1} \mathrm{hr}^{-1}\right)\end{array}$ & $\begin{array}{c}\text { STD } \\
\left(\mathrm{pM} \mathrm{g}^{-1} \mathbf{h r}^{-1}\right)\end{array}$ \\
\hline \multirow[t]{4}{*}{ July 2012} & 0 & 3 & 8.684 & 0.000 & 0.000 & 0.000 \\
\hline & 24 & 9 & 21.728 & 13.044 & 0.544 & 0.147 \\
\hline & 48 & 8 & 22.185 & 13.501 & 0.281 & 0.041 \\
\hline & 72 & 7 & 21.744 & 13.060 & 0.181 & 0.077 \\
\hline \multirow[t]{4}{*}{ March 2012} & 0 & 3 & 11.893 & 0.000 & 0.000 & 0.000 \\
\hline & 24 & 6 & 26.880 & 14.987 & 0.624 & 0.062 \\
\hline & 48 & 9 & 38.255 & 26.361 & 0.549 & 0.091 \\
\hline & 72 & 9 & 39.754 & 27.861 & 0.387 & 0.048 \\
\hline \multirow[t]{4}{*}{ October 2012} & 0 & 3 & 6.300 & 0.000 & 0.000 & 0.000 \\
\hline & 24 & 9 & 16.913 & 10.613 & 0.442 & 0.063 \\
\hline & 48 & 9 & 22.124 & 15.824 & 0.330 & 0.069 \\
\hline & 72 & 9 & 26.533 & 20.233 & 0.281 & 0.042 \\
\hline
\end{tabular}




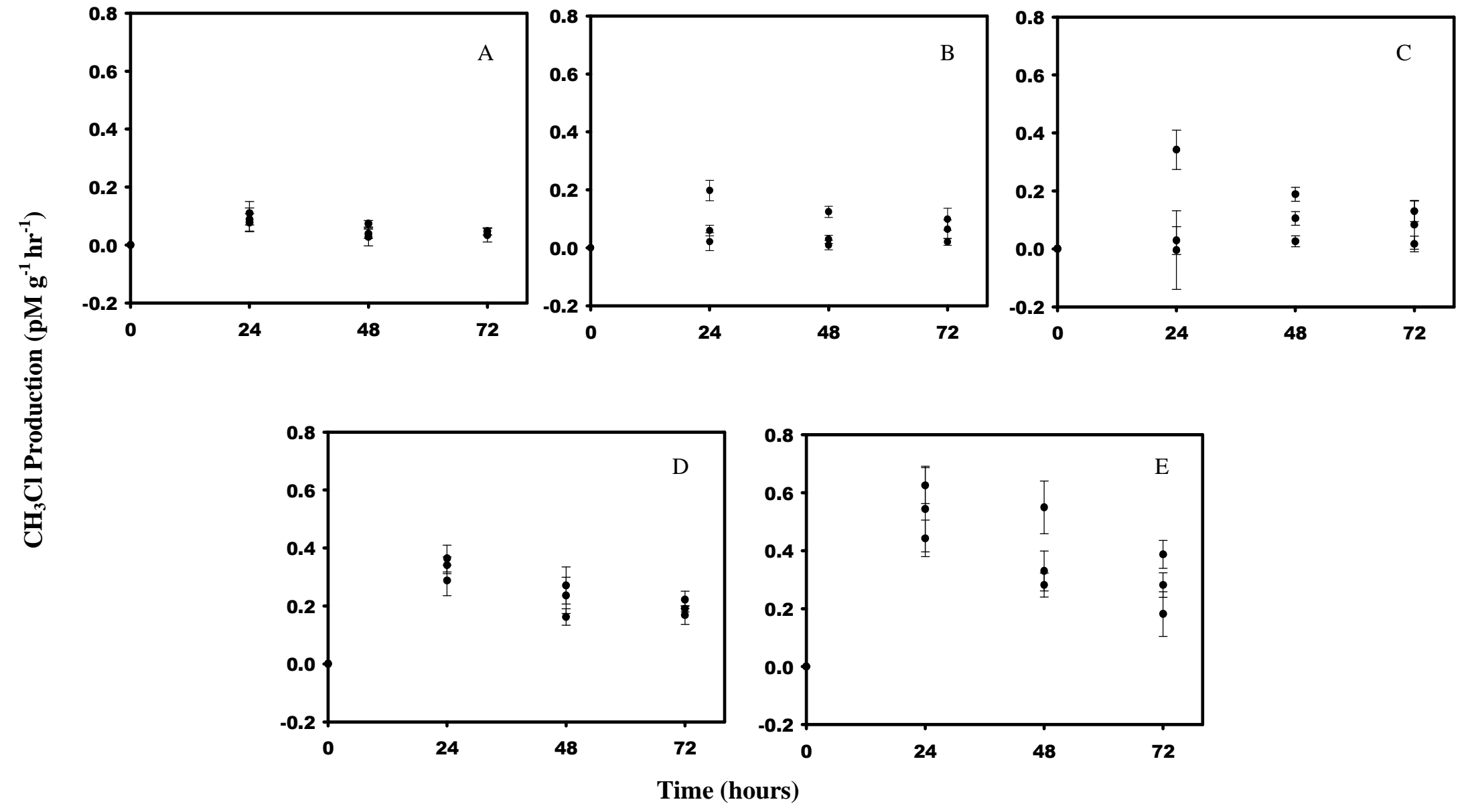

Figure 3.1: Methyl chloride $\left(\mathrm{CH}_{3} \mathrm{Cl}\right)$ production by periphyton, over time, for $0 \%$ (A), $0.1 \% \circ(\mathrm{B}), 1 \% \circ(\mathrm{C}), 5 \%$ (D), and $10 \%$ (E) salt water treatments ( $\mathrm{n}=3$ for each treatment). Standard deviations are noted. 


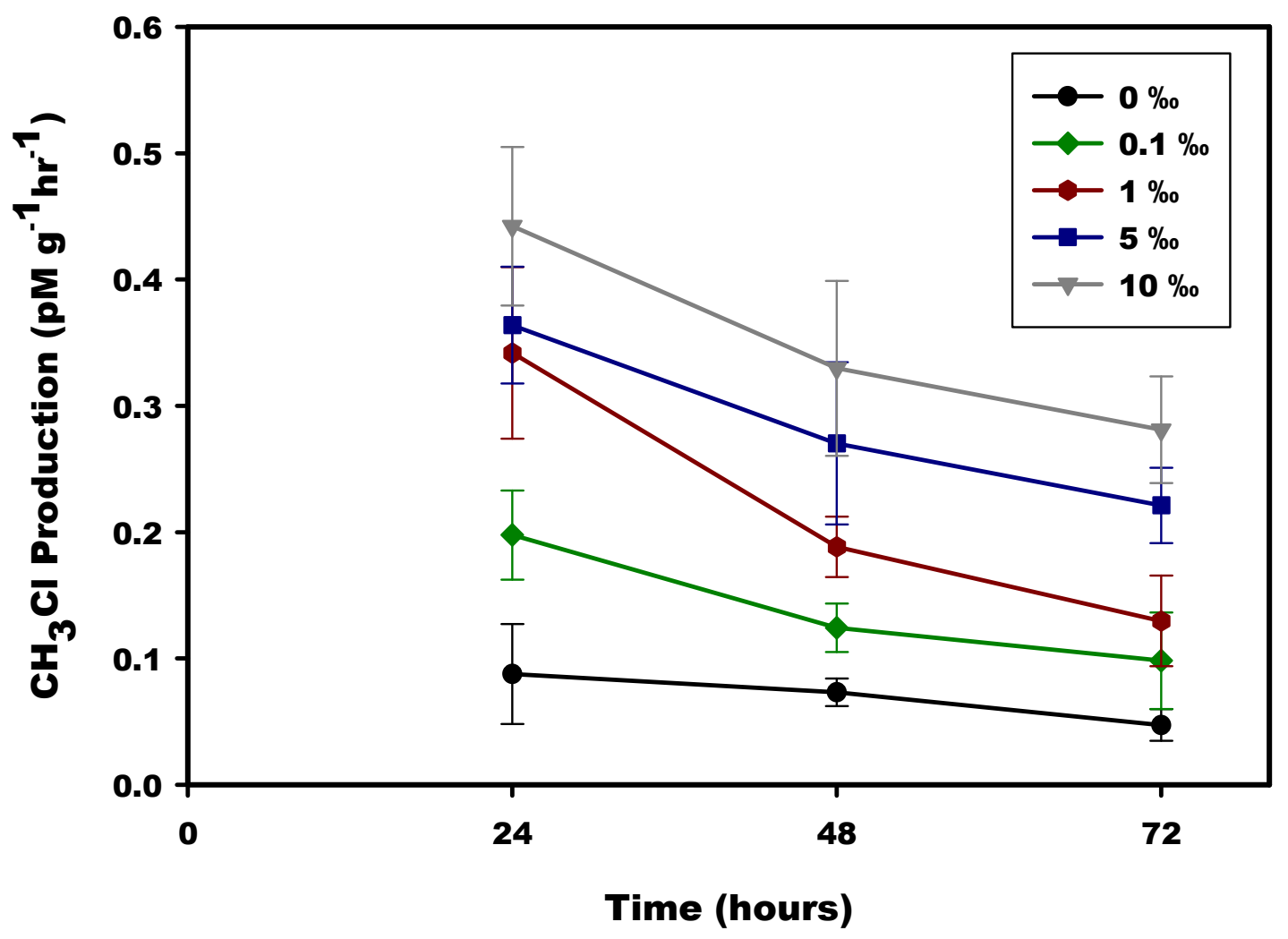

Figure 3.2: Methyl chloride production $\left(\mathrm{pM} \mathrm{g}^{-1} \mathrm{hr}^{-1}\right)$ for one trial from each salt water treatment. All salt water treatments except for the 5\%o were performed during October 2012. 5\%o trial was completed in February 2013. 


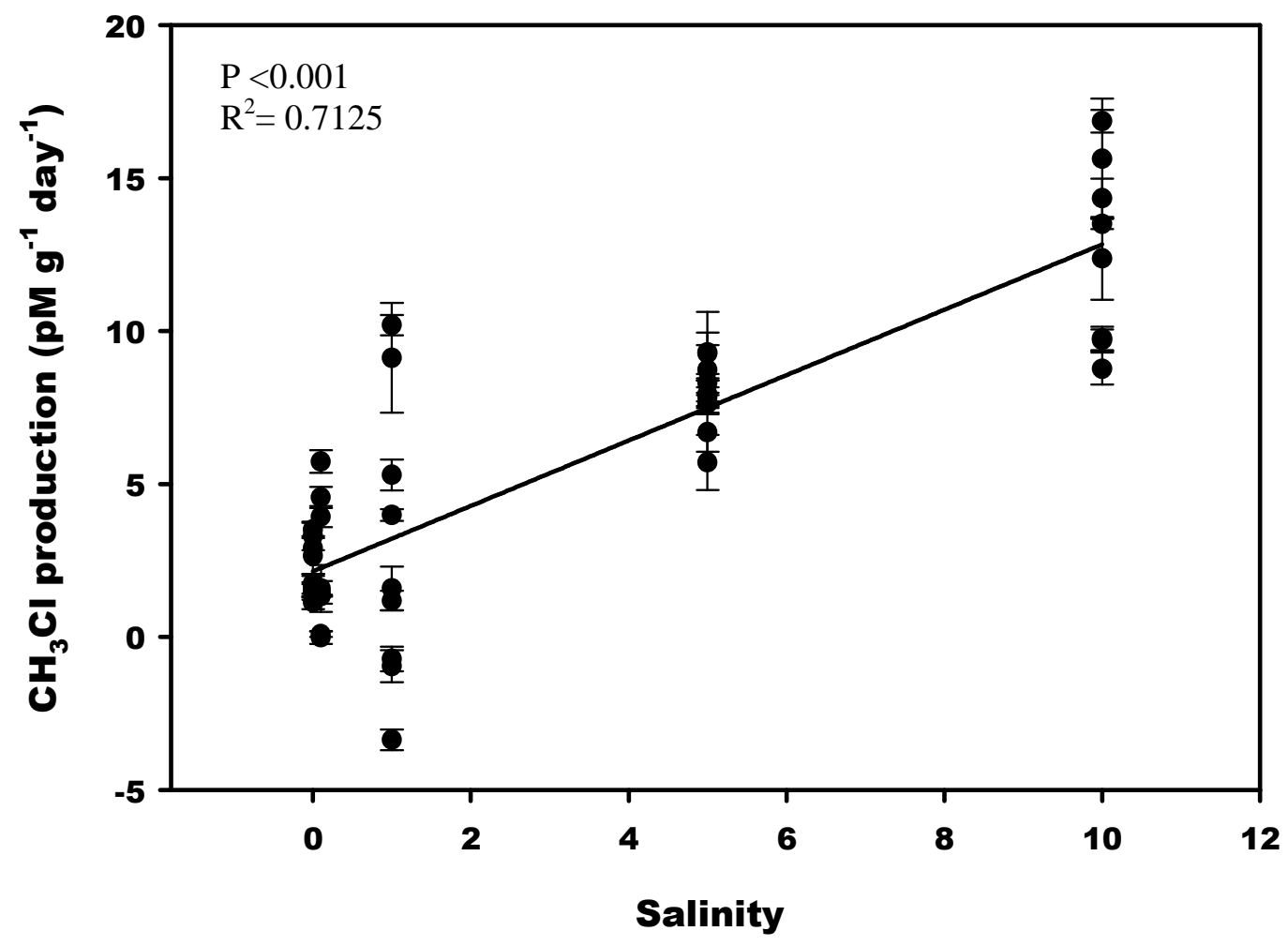

Figure 3.3: The relationship between methyl chloride $\left(\mathrm{CH}_{3} \mathrm{Cl}\right)$ production and salinity $(n=44)$ after 24 hours. Standard deviations are noted. 


\section{Methyl bromide}

Initial results show that periphyton mats were not a producer of methyl bromide in the majority of the freshwater $(0 \%$ ) experiments. However one experiment, which was ran in October of 2012, showed some production of methyl bromide after 24 hours (Table 3.6). Production rates for the freshwater experiments ranged from -0.00025 to $0.00185 \mathrm{pM} \mathrm{g}^{-1} \mathrm{hr}^{-1}$ after 24 hours, -0.00022 to $-0.00078 \mathrm{pM} \mathrm{g}^{-1} \mathrm{hr}^{-1}$ after 48 hours, and -0.00042 to $-0.00061 \mathrm{pM} \mathrm{g}^{-1} \mathrm{hr}^{-1}$ after 72 hours (Figure 3.4 and Table 3.6).

Experiments from the $0.1 \%$ o saltwater treatments showed some production for methyl bromide; however, the experiment conducted in January 2013 did not produce any methyl bromide at any of the sampling times. Production rates for these experiments ranged from -0.00149 to $0.00427 \mathrm{pM} \mathrm{g}^{-1} \mathrm{hr}^{-1}$ after 24 hours, -0.00092 to $0.00427 \mathrm{pM} \mathrm{g}^{-1}$ $\mathrm{hr}^{-1}$ after 48 hours, and -0.00056 to $0.00166 \mathrm{pM} \mathrm{g}^{-1} \mathrm{hr}^{-1}$ after 72 hours (Figure 3.4 and Table 3.7).

The 1, 5, and $10 \%$ saltwater treatments found production of methyl bromide during all experiments and times, except at the 72 hour sampling time during the October $20121 \%$ and $10 \%$ experiments (Tables 3.8-3.10). Production rates for the $1 \%$ saltwater treatment ranged from 0.00175 to $0.01413 \mathrm{pM} \mathrm{g}^{-1} \mathrm{hr}^{-1}$ after 24 hours, 0.00059 to 0.01124 $\mathrm{pM} \mathrm{g}^{-1} \mathrm{hr}^{-1}$ after 48 hours, and -0.00029 to $0.00580 \mathrm{pM} \mathrm{g}^{-1} \mathrm{hr}^{-1}$ after 72 hours (Figure 3.4 and Table 3.8). Methyl bromide production rates for the 5\%o saltwater treatment ranged from 0.00884 to $0.01497 \mathrm{pM} \mathrm{g}^{-1} \mathrm{hr}^{-1}$ after 24 hours, 0.00307 to $0.00627 \mathrm{pM} \mathrm{g}^{-1} \mathrm{hr}^{-1}$ after 48 hours, and 0.00119 to $0.00354 \mathrm{pM} \mathrm{g}^{-1} \mathrm{hr}^{-1}$ after 72 hours (Figure 3.4 and Table 3.9). Lastly, production rates for the $10 \%$ saltwater treatment ranged from 0.00913 to 0.03038 
$\mathrm{pM} \mathrm{g}^{-1} \mathrm{hr}^{-1}$ after 24 hours, 0.00353 to $0.01647 \mathrm{pM} \mathrm{g}^{-1} \mathrm{hr}^{-1}$ after 48 hours, and -0.00011 to $0.01237 \mathrm{pM} \mathrm{g}^{-1} \mathrm{hr}^{-1}$ after 72 hours (Figure 3.4 and Table 3.10). Overall, a significant positive relationship was found between methyl bromide production and salinity $\left(\mathrm{p}<0.001, \mathrm{R}^{2}=0.474, \mathrm{n}=42\right.$ ) (Figure 3.5). Further analysis of methyl bromide data was not performed due to reasons that will be explained in Chapter 4. 
Table 3.6: Average values for $0 \%$ (freshwater) experiments for methyl bromide $\left(\mathrm{CH}_{3} \mathrm{Br}\right)$ concentrations and production over time for all trials. Standard deviations are noted.

\begin{tabular}{|c|c|c|c|c|c|c|}
\hline $\begin{array}{l}\text { Expe riment } \\
\text { (month/year) }\end{array}$ & $\begin{array}{l}\text { Time } \\
\text { (hrs) }\end{array}$ & $\mathbf{n}$ & $\begin{array}{c}\mathrm{CH}_{3} \mathrm{Br} \\
\text { Concentration } \\
\left(\mathbf{p M ~ g}^{-1}\right)\end{array}$ & $\begin{array}{c}\mathrm{CH}_{3} \mathrm{Br} \\
\text { Production } \\
\left(\mathrm{pM} \mathrm{g}^{-1}\right)\end{array}$ & $\begin{array}{c}\mathrm{CH}_{3} \mathrm{Br} \\
\text { Production } \\
\left(\mathbf{p M} \mathbf{g}^{-1} \mathbf{h r}^{-1}\right)\end{array}$ & $\begin{array}{c}\text { STD } \\
\left(\mathrm{pM}^{-1} \mathbf{h r}^{-1}\right)\end{array}$ \\
\hline \multirow[t]{4}{*}{ October 2012} & 0 & 3 & 0.070 & 0.000 & 0.00000 & 0.00000 \\
\hline & 24 & 5 & 0.114 & 0.044 & 0.00185 & 0.00203 \\
\hline & 48 & 3 & 0.059 & -0.011 & -0.00022 & 0.00027 \\
\hline & 72 & 3 & 0.040 & -0.030 & -0.00042 & 0.00012 \\
\hline \multirow[t]{4}{*}{ January 2013} & 0 & 3 & 0.056 & 0.000 & 0.00000 & 0.00000 \\
\hline & 24 & 9 & 0.043 & -0.013 & -0.00053 & 0.00050 \\
\hline & 48 & 8 & 0.027 & -0.029 & -0.00061 & 0.00036 \\
\hline & 72 & 0 & & & & \\
\hline \multirow[t]{4}{*}{ February 2013} & 0 & 3 & 0.052 & 0.000 & 0.00000 & 0.00000 \\
\hline & 24 & 7 & 0.046 & -0.006 & -0.00025 & 0.00068 \\
\hline & 48 & 9 & 0.014 & -0.037 & -0.00078 & 0.00025 \\
\hline & 72 & 7 & 0.020 & -0.032 & -0.00044 & 0.00012 \\
\hline
\end{tabular}

Table 3.7: Average values for $0.1 \%$ experiments for methyl bromide $\left(\mathrm{CH}_{3} \mathrm{Br}\right)$ concentrations and production over time for all trials. Standard deviations are noted.

\begin{tabular}{|c|c|c|c|c|c|c|}
\hline $\begin{array}{c}\text { Expe riment } \\
\text { (month/year) }\end{array}$ & $\begin{array}{l}\text { Time } \\
\text { (hrs) }\end{array}$ & $\mathbf{n}$ & 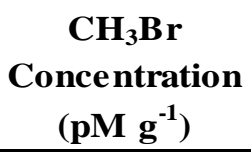 & $\begin{array}{c}\mathrm{CH}_{3} \mathbf{B r} \\
\text { Production } \\
\left(\mathbf{p M ~ g}^{-1}\right) \\
\end{array}$ & $\begin{array}{c}\mathrm{CH}_{3} \mathrm{Br} \\
\text { Production } \\
\left(\mathbf{p M ~ g}^{-1} \mathbf{h r}^{-1}\right)\end{array}$ & $\begin{array}{c}\text { STD } \\
\left(\mathbf{p M ~ g}^{-1} \mathbf{h r}^{-1}\right)\end{array}$ \\
\hline \multirow[t]{4}{*}{ October 2012} & 0 & 3 & 0.084 & 0.000 & 0.00000 & 0.00000 \\
\hline & 24 & 7 & 0.049 & -0.036 & -0.00149 & 0.00082 \\
\hline & 48 & 0 & & & & \\
\hline & 72 & 3 & 0.204 & 0.119 & 0.00166 & 0.00412 \\
\hline \multirow[t]{4}{*}{ December 2012} & 0 & 3 & 0.009 & 0.000 & 0.00000 & 0.00000 \\
\hline & 24 & 7 & 0.112 & 0.103 & 0.00427 & 0.00145 \\
\hline & 48 & 1 & 0.027 & 0.018 & 0.00037 & 0.00000 \\
\hline & 72 & 0 & & & & \\
\hline \multirow[t]{4}{*}{ January 2013} & 0 & 3 & 0.060 & 0.000 & 0.00000 & 0.00000 \\
\hline & 24 & 3 & 0.012 & -0.048 & -0.00200 & 0.00010 \\
\hline & 48 & 9 & 0.016 & -0.044 & -0.00092 & 0.00010 \\
\hline & 72 & 9 & 0.020 & -0.040 & -0.00056 & 0.00009 \\
\hline
\end{tabular}


Table 3.8: Average values for $1 \%$ experiments for methyl bromide $\left(\mathrm{CH}_{3} \mathrm{Br}\right)$ concentrations and production over time for all trials. Standard deviations are noted.

\begin{tabular}{|c|c|c|c|c|c|c|}
\hline $\begin{array}{c}\text { Experiment } \\
\text { (month/year) }\end{array}$ & $\begin{array}{l}\text { Time } \\
\text { (hrs) }\end{array}$ & $\mathbf{n}$ & $\begin{array}{c}\mathrm{CH}_{3} \mathrm{Br} \\
\text { Concentration } \\
\left(\mathrm{pM} \mathrm{g}^{-1}\right) \\
\end{array}$ & $\begin{array}{c}\mathrm{CH}_{3} \mathrm{Br} \\
\text { Production } \\
\left(\mathrm{pM} \mathrm{g}^{-1}\right) \\
\end{array}$ & $\begin{array}{c}\mathrm{CH}_{3} \mathbf{B r} \\
\text { Production } \\
\left(\mathbf{p M} \mathbf{g}^{-1} \mathbf{h r}^{-1}\right) \\
\end{array}$ & $\begin{array}{c}\text { STD } \\
\left(\mathrm{pM} \mathrm{g}^{-1} \mathbf{h r}^{-1}\right)\end{array}$ \\
\hline \multirow[t]{4}{*}{ July 2012} & 0 & 3 & 0.078 & 0.000 & 0.00000 & 0.00000 \\
\hline & 24 & 8 & 0.120 & 0.042 & 0.00175 & 0.00319 \\
\hline & 48 & 9 & 0.106 & 0.028 & 0.00059 & 0.00087 \\
\hline & 72 & 9 & 0.131 & 0.053 & 0.00073 & 0.00127 \\
\hline \multirow[t]{4}{*}{ March 2012} & 0 & 3 & 0.231 & 0.000 & 0.00000 & 0.00000 \\
\hline & 24 & 9 & 0.570 & 0.339 & 0.01413 & 0.00393 \\
\hline & 48 & 9 & 0.771 & 0.539 & 0.01124 & 0.00222 \\
\hline & 72 & 9 & 0.649 & 0.418 & 0.00580 & 0.00182 \\
\hline \multirow[t]{4}{*}{ October 2012} & 0 & 3 & 0.073 & 0.000 & 0.00000 & 0.00000 \\
\hline & 24 & 9 & 0.120 & 0.046 & 0.00193 & 0.00193 \\
\hline & 48 & 6 & 0.208 & 0.135 & 0.00281 & 0.00637 \\
\hline & 72 & 2 & 0.052 & -0.021 & -0.00029 & 0.00021 \\
\hline
\end{tabular}

Table 3.9: Average values for 5\%o experiments for methyl bromide $\left(\mathrm{CH}_{3} \mathrm{Br}\right)$ concentrations and production over time for all trials. Standard deviations are noted.

\begin{tabular}{|c|c|c|c|c|c|c|}
\hline $\begin{array}{c}\text { Experiment } \\
\text { (month/year) }\end{array}$ & $\begin{array}{l}\text { Time } \\
(\text { hrs })\end{array}$ & $\mathbf{n}$ & $\begin{array}{c}\mathrm{CH}_{3} \mathrm{Br} \\
\text { Concentration } \\
\left(\mathrm{pM} \mathrm{g}^{-1}\right) \\
\end{array}$ & $\begin{array}{c}\mathrm{CH}_{3} \mathrm{Br} \\
\text { Production } \\
\left(\mathrm{pM} \mathrm{g}^{-1}\right) \\
\end{array}$ & $\begin{array}{c}\mathrm{CH}_{3} \mathrm{Br} \\
\text { Production } \\
\left(\mathrm{pM} \mathrm{g}^{-1} \mathbf{h r}^{-1}\right) \\
\end{array}$ & $\begin{array}{c}\text { STD } \\
\left(\mathrm{pM} \mathrm{g}^{-1} \mathbf{h r}^{-1}\right)\end{array}$ \\
\hline \multirow[t]{4}{*}{ February 18, 2013} & 0 & 3 & 0.081 & 0.000 & 0.00000 & 0.00000 \\
\hline & 24 & 9 & 0.293 & 0.212 & 0.00884 & 0.00132 \\
\hline & 48 & 8 & 0.241 & 0.160 & 0.00334 & 0.00128 \\
\hline & 72 & 9 & 0.172 & 0.092 & 0.00128 & 0.00082 \\
\hline \multirow[t]{4}{*}{ February 26, 2013} & 0 & 3 & 0.088 & 0.000 & 0.00000 & 0.00000 \\
\hline & 24 & 9 & 0.319 & 0.231 & 0.00963 & 0.00212 \\
\hline & 48 & 9 & 0.236 & 0.148 & 0.00307 & 0.00105 \\
\hline & 72 & 9 & 0.174 & 0.086 & 0.00119 & 0.00085 \\
\hline \multirow[t]{4}{*}{ March 2013} & 0 & 3 & 0.043 & 0.000 & 0.00000 & 0.00000 \\
\hline & 24 & 9 & 0.403 & 0.359 & 0.01497 & 0.00209 \\
\hline & 48 & 9 & 0.344 & 0.301 & 0.00627 & 0.00240 \\
\hline & 72 & 8 & 0.298 & 0.255 & 0.00354 & 0.00068 \\
\hline
\end{tabular}


Table 3.10: Average values for $10 \%$ oxperiments for methyl bromide $\left(\mathrm{CH}_{3} \mathrm{Br}\right)$ concentrations and production over time for all trials. Standard deviations are noted.

\begin{tabular}{|c|c|c|c|c|c|c|}
\hline $\begin{array}{c}\text { Experiment } \\
\text { (month/year) }\end{array}$ & $\begin{array}{l}\text { Time } \\
(\text { hrs })\end{array}$ & $\mathbf{n}$ & 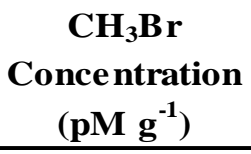 & 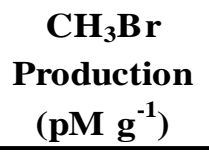 & $\begin{array}{c}\mathrm{CH}_{3} \mathrm{Br} \\
\text { Production } \\
\left(\mathbf{p M ~ g}^{-1} \mathbf{h r}^{-1}\right) \\
\end{array}$ & $\begin{array}{c}\text { STD } \\
\left(\mathrm{pM} \mathrm{g}^{-1} \mathbf{h r}^{-1}\right)\end{array}$ \\
\hline \multirow[t]{4}{*}{ July 2012} & 0 & 3 & 0.086 & 0.000 & 0.00000 & 0.00000 \\
\hline & 24 & 9 & 0.325 & 0.239 & 0.00994 & 0.00465 \\
\hline & 48 & 8 & 0.259 & 0.173 & 0.00361 & 0.00337 \\
\hline & 72 & 6 & 0.141 & 0.055 & 0.00076 & 0.00123 \\
\hline \multirow[t]{4}{*}{ March 2012} & 0 & 3 & 0.144 & 0.000 & 0.00000 & 0.00000 \\
\hline & 24 & 6 & 0.873 & 0.729 & 0.03038 & 0.00517 \\
\hline & 48 & 9 & 0.934 & 0.790 & 0.01647 & 0.00490 \\
\hline & 72 & 9 & 1.034 & 0.891 & 0.01237 & 0.00085 \\
\hline \multirow[t]{4}{*}{ October 2012} & 0 & 3 & 0.087 & 0.000 & 0.00000 & 0.00000 \\
\hline & 24 & 9 & 0.306 & 0.219 & 0.00913 & 0.00334 \\
\hline & 48 & 6 & 0.256 & 0.169 & 0.00353 & 0.00308 \\
\hline & 72 & 7 & 0.079 & -0.008 & -0.00011 & 0.00091 \\
\hline
\end{tabular}




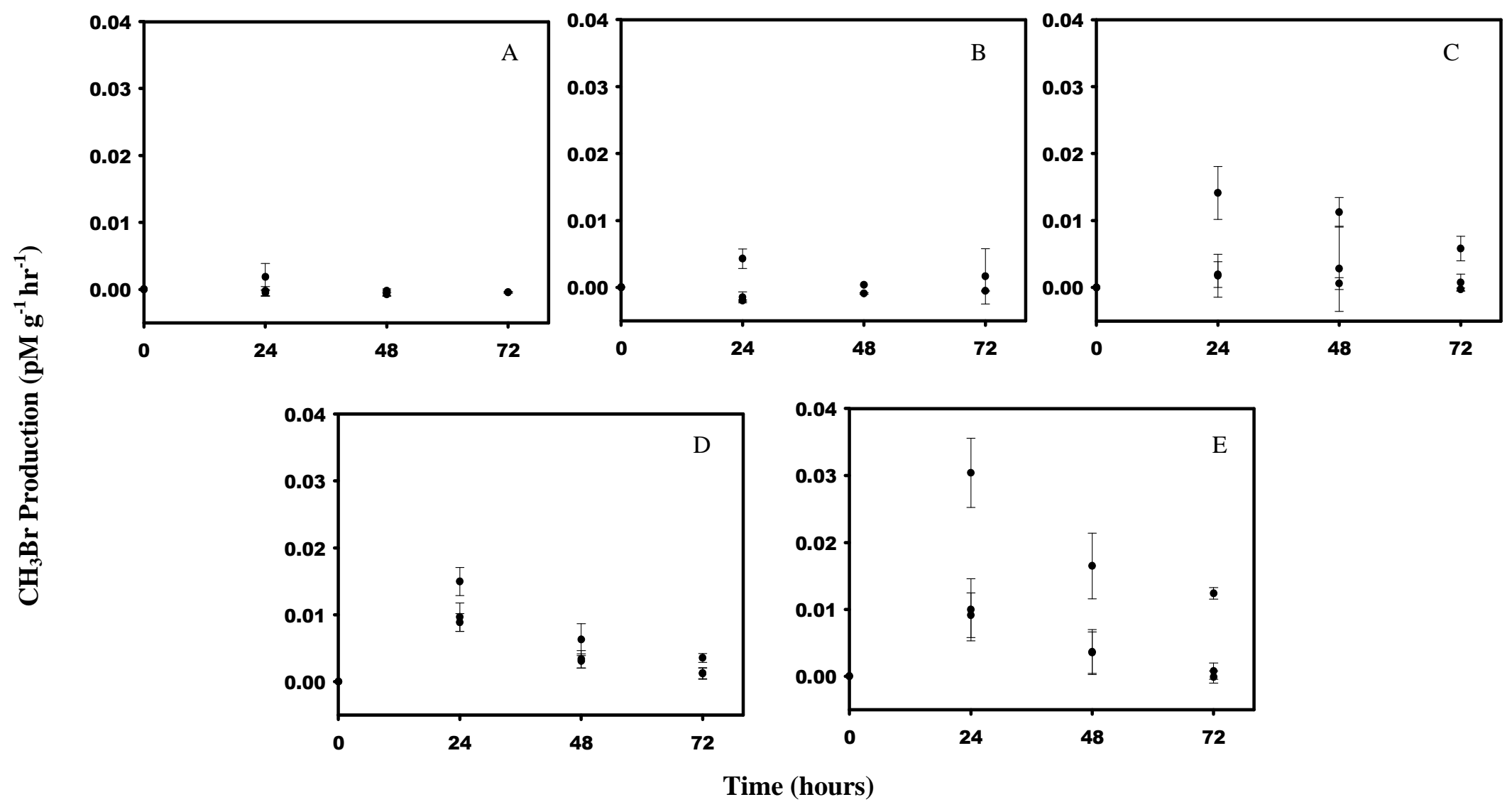

Figure 3.4: Methyl bromide $\left(\mathrm{CH}_{3} \mathrm{Br}\right)$ production by periphyton, over time, for $0 \%$ (A), $0.1 \%$ \% (B), $1 \%$ (C), $5 \%$ (D), and $10 \%$ (E) salt water treatments ( $\mathrm{n}=3$ for each treatment). Standard deviations are noted. 


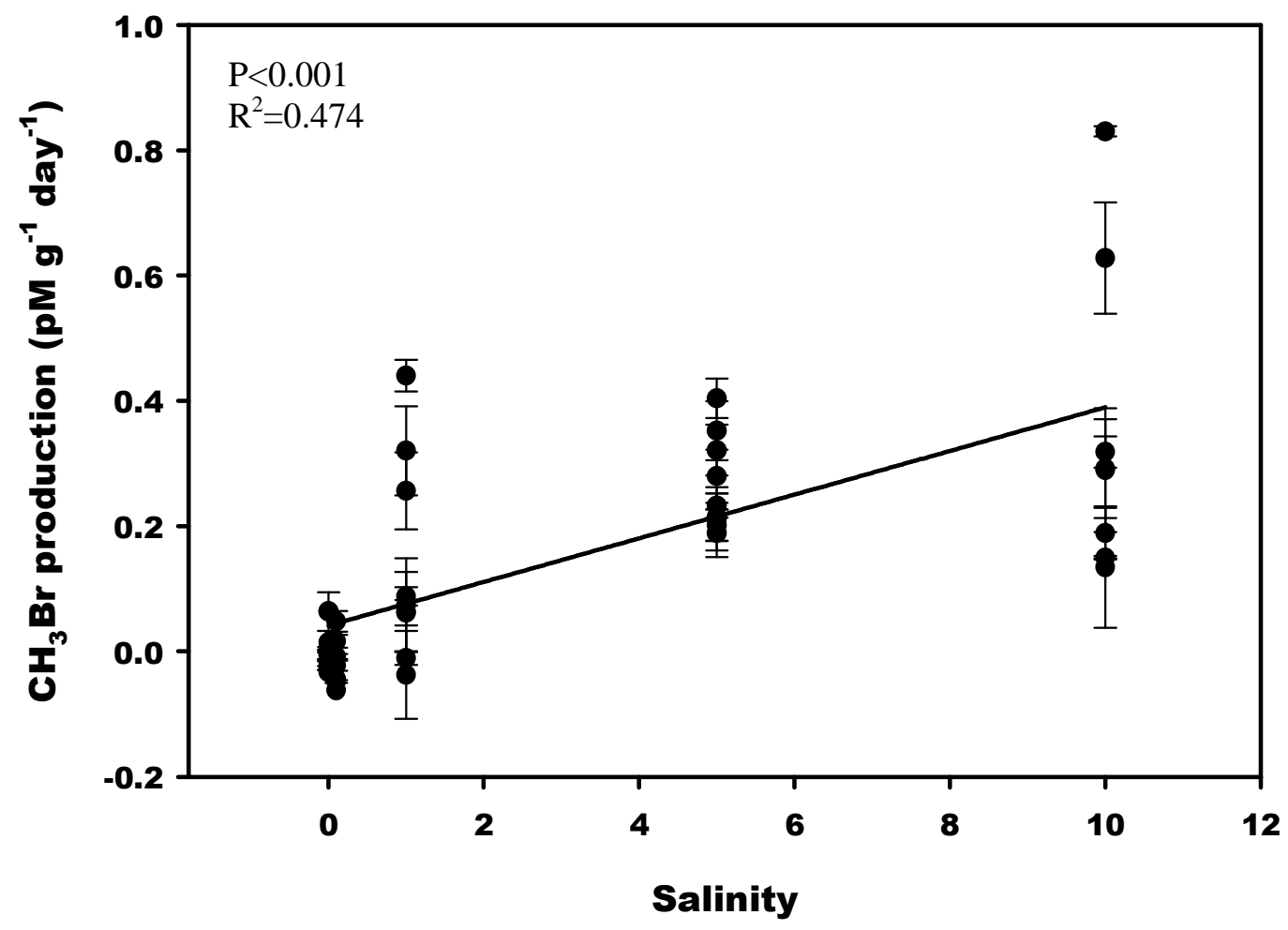

Figure 3.5: The relationship between methyl bromide $\left(\mathrm{CH}_{3} \mathrm{Br}\right)$ production and salinity $(\mathrm{n}=42)$ after 24 hours. Standard deviations are noted. 


\section{Chapter 4}

\section{Discussion}

\section{Methyl chloride}

Prior to the start of this research, it was hypothesized that calcareous periphyton mats would produce methyl chloride and that with increasing time the amount of production would also increase. After completing all experiments, the first hypothesis was supported; whereas, the second was not. This study has shown that calcareous periphyton mats, in general, produce methyl chloride; however, production rates do not increase with increasing time. In most cases, the 24 hour value had the highest production rate with the 48 and 72 hour production rates being lower than the previous. These results suggest that something became limited within the periphyton quartz tube environment after 24 hours. However, since this drop in production rates occurred in both the freshwater $(0 \%$ ) and the majority of the salt water treatments, the additional salts added to the $0.1,1,5$, and $10 \%$ treatments can be eliminated. This leaves only the components of the artificial marsh water as the potential limiting substance and could imply that the ratio of periphyton mass to marsh water was too high. It is also possible that the periphyton mats have a daily variability in methyl halide emissions. Other researchers have found variability in methyl halide emissions from rice paddies (Redeker et al. 2002), temperate grasslands (Rhew and Abel 2007), coastal salt marshes (Rhew et al. 2002), and temperate forest litters (Blei and Heal 2011). Further research would help to elucidate whether the drop in production rates after 24 hours was due to variability or 
to a limiting substance within the quartz tube environment.

Further research could consist of altering the grams of periphyton to liter of artificial marsh water or salt water mixture. Since this research consisted of using 5 w.w. grams of periphyton originally $(25 \mathrm{~g} / \mathrm{L})$ and was later increased to 10 grams $(50 \mathrm{~g} / \mathrm{L})$, the amount of periphyton should be dropped to less than $25 \mathrm{~g} / \mathrm{L}$ to see if the drop in production rates still occurs after 24 hours. Additional experiments where the time course study lasts longer than 72 hours would also help to elucidate whether the drop in productions rates is due to normal variability or a limiting substance. These experiments should keep the same concentration $(50 \mathrm{~g} / \mathrm{L})$ that was used in the later stages of this study. It could also be beneficial to take water samples directly from the microcosms; however, due to the walking distance from the research greenhouse to the laboratory this option was not feasible.

Another hypothesis at the start of this research was as salinity increases the production rate of methyl chloride would also increase. Overall, this hypothesis was accepted since a significant positive correlation was found between salinity and the production rate of methyl chloride. However, this research has also shown that there is not a significant difference between the production rates in the freshwater and the two lowest salinity concentration experiments. The lowest salinity concentration of $0.1 \%$ o was so small that there simply weren't enough added salts to make an overall difference in the production rates. In contrast, $1 \%$ o salt water treatment had just enough salts added where it was hypothesized that a slight increase in production rates would occur. It should be noted that the $1 \%$ o salt water treatments also had some of the greatest 
variability of all the experiments run during this study. Even though all of the periphyton exposed to the $1 \%$ o salt water was prepared and analyzed in the exact same manner, there was a lot of variation between production rates, especially after 24 hours. Further replicates of this trial would be beneficial to see if any of the production rates found during this study were in fact outliers.

Some of the variability found within the freshwater and saltwater treatments, and possibly the drop in the production rates after 24 hours, could also be explained by phenomenon known as the "bottle effect". The "bottle effect" can occur when assemblages, such as periphyton mats, are placed in confined spaces like quartz tubes. This confinement has been known to produce variability in laboratory experiments in various types of aquatic microbiological studies (Marrase et al. 1992; Krammer et al. 2008; Hammes et al. 2010).

\section{Methyl bromide}

It was also hypothesized that periphyton mats would be a producer of methyl bromide and that like methyl chloride the production rates would increase with both increasing time and salinity. Instead, the results of this study suggest that periphyton mats are a consumer of methyl bromide in freshwater and low salinity environments ( $0.1 \%$ or less) and a producer of methyl bromide in environments with salinity greater than or equal to $1 \%$. However, some of the methyl bromide data points may be falsely low due to an unknown chromatographic peak, which would start to appear before the methyl bromide peak was finished forming. In addition, this unknown peak was only unique to water samples that had previous exposure to periphyton. This suggests that 
periphyton mats are producing some type of compound that has a similar retention time to methyl bromide.

Overall, the methyl bromide data analysis was not carried out to the same level as the analysis for methyl chloride due to the occurrence of the unknown transient peak. This peak would also make it difficult to determine the peak area of methyl bromide in some of the water samples and as a result the methyl bromide peak data is missing for some of the samples. However, a regression analysis was still carried out with the assumption that if a significant positive relationship was found between methyl bromide and salinity, the relationship between the two variables would only be stronger if the methyl bromide peaks would have been able to form completely, and if values were found for all samples. As with methyl chloride, there was a significant positive relationship between the production rates of methyl bromide and salinity.

The production rates of the methyl bromide also declined, like methyl chloride, between 24 and 48 hours and then again between 48 and 72 hours. It is not known if this drop in production rates is significant due to the peak issues with methyl bromide and the unknown compound. In addition, the freshwater and the lower salinity experiments did not have a large enough sample size to run a t-test.

Since there were notable issues with the methyl bromide data, it would be beneficial to redo all of the freshwater and salinity experiments for this compound. This would help to elucidate periphyton role in methyl bromide production. However, before further experiments are done, the unknown peak should be investigated to see if the methyl bromide and the unknown peaks could be separated more effectively. It 
should also be mentioned that since periphyton has never been studied with respects to methyl halides emissions, in general, it cannot be known if other researchers had the same issue with the methyl bromide peaks.

\section{Comparisons to other methyl halide studies}

The majority of scientific studies involving methyl halide production rates have focused on field-based studies (Redeker et. al 2000; Redeker et.al 2002; Drewer et. al 2006; Blei et. al 2010; Blei and Heal 2011). However, due to methodological differences, production rates found within this laboratory-based thesis study cannot be directly compared to results from field-based research. In addition to this thesis study, other laboratory-based studies for methyl halide production from organisms have occurred. Some of these studies have focused on wood-rotting fungi (Wuosmaa et. al 1990; Saxena et.al 1998), ectomycorrhizal fungi (EMF) (Redeker et. al 2004), and marine phytoplankton (Tait and Moore 1995).

In comparison to another laboratory-based study, freshwater methyl chloride production rates found within this thesis study were two orders of magnitude smaller than the lowest rates found in an EMF study $\left(0.000037-0.000053 \mu \mathrm{g} \mathrm{g}^{-1} \mathrm{day}^{-1} ; 0.0010-100 \mu \mathrm{g}\right.$ $\mathrm{g}^{-1}$ day $^{-1}$, respectively)(Redeker et. al 2004). However, the production rates from the $10 \%$ o salt treatment had rates that were one order of magnitude smaller than the low estimates found in the EMF study (0.00020-0.00033 $\mu \mathrm{g} \mathrm{g}^{-1} \mathrm{day}^{-1} ; 0.0010 \mu \mathrm{g} \mathrm{g}^{-1} \mathrm{day}^{-1}$, respectively). In another comparison, results from this study were around two orders of magnitude smaller than a study that looked at wood-rotting fungi $\left(0.10-0.14 ; 7-30 \mathrm{pmol} \mathrm{g}^{-1} \mathrm{day}^{-1}\right.$, respectively) (Wuosmaa et. al 1990) and around five orders of magnitude smaller in 
another wood-rotting fungi study $\left(0.00011-0.00014 ; 325 \mathrm{nmol} \mathrm{g}^{-1} \mathrm{day}^{-1}\right.$, respectively (Saxena et.al 1998). Overall, these comparisons show that calcareous periphyton mats have low production rates when compared to other organisms based on similar mass and methodologies.

\section{Modeling and climate change}

Once production rates for methyl chloride were determined, a modeling program was used to give a best estimate of the amount of methyl chloride produced by calcareous periphyton mats in south Florida $(150 \mathrm{~km}$ x $150 \mathrm{~km})$. This model was based off the dry weight periphyton densities found in the Lee et al. (2013) paper and dry weight values and also production rates ( 0 and $10 \%$ treatments) determined during this thesis study. Sawgrass was also used as a proxy for the location of periphyton on vegetation maps for south Florida, since maps do not currently exist that show the exact locations and densities of periphyton. Freshwater estimates averaged $\sim 2.0 \mathrm{~kg}$ of methyl chloride produced by periphyton mats during six months of a wet season. Overall, this amount is quite small when compared to the amount produced by other sources of methyl chloride. For instance, the smallest amount reported on Table 1.1. was $2.4 \mathrm{Gg}$ of methyl chloride produced per year $(1.2 \mathrm{Gg}$ in 6 months) from rice paddies. Therefore results from this study, list calcareous periphyton mats as the smallest known source of methyl chloride. Due to reasons discussed previously an estimate for methyl bromide production over the same six month period was not determined.

An average estimate of $\sim 8 \mathrm{~kg}$ of methyl chloride was also found to be produced for the $10 \%$ salt water (brackish water) treatment. Even though this amount is around 
three and half times larger than the freshwater estimate, it is still quite small when compared to the other methyl chloride sources. It does, however, show the importance of increased salinity levels in a freshwater system that may occur due to global climate change and rising sea levels.

\section{Future directions}

The results from this experiment could be taken into a variety of directions. One possible direction could be to expose periphyton to an eutrophic environment to see how production rates change, if any, in freshwater and in various salinity environments. Historically, the Florida Everglades is a phosphorus-limited oligotrophic environment but due to agricultural influences the area is becoming more nutrient rich over time (Noe et al. 2001: Gaiser et al. 2006). This direction would produce results that would be useful in elucidating how anthropogenic activities influence methyl halide production from periphyton mats.

Another avenue for future research should look exclusively at the enzyme mediated methyl transferase reactions. There seems to be a general agreement among scientists in the role of methyl transferase in the generation of methyl halides; however the exact mechanisms involved in these reactions are poorly understood (Manley 2002; White et al. 2005; Manley et al. 2006). Originally, research was planned in this area but due to the capabilities of the pre-concentration system used in this thesis study, it was found not to be feasible. This was due to the small volume of the headspace that would need to be injected into the pre-concentration system for this research to take place.

Within the last couple of years, wetlands with characteristics similar to the Florida 
Everglades and calcareous periphyton mats have been found in other parts of the Western Hemisphere. These locations include the southeastern coast of the Yucatan Peninsula $\left(\sim 6500 \mathrm{~km}^{2}\right)$, the New River Lagoon in Belize ( $23 \mathrm{~km}$ long by $750 \mathrm{~m}$ wide), and the Black River Morass in the southwestern region of Jamaica $\left(\sim 1488 \mathrm{~km}^{2}\right)$ (La Hee and Gaiser 2012). A comparative study would be beneficial to see if methyl halide production rates found in each of these systems are similar to rates found within the Florida Everglades. This would give a better estimate in determining the overall source strength of periphyton mats in generating methyl chloride and methyl bromide. As a result, this would help in providing a more accurate estimate of periphyton's role in the overall global budgets for these compounds. 


\section{References}

Allison, N., L. Bindoff, R.A. Bindschadler, P.M. Cox, N. de Noblet, M.H. England, J.E. Francis, N.Gruber, A.M. Haywood, D.J. Karoly, G. Kaser, C. Le Quéré, T.M. Lenton, M.E. Mann, B.I. McNeil, A.J. Pitman, S. Rahmstorf, E. Rignot, H.J. Schellnhuber, S.H. Schneider, S.C. Sherwood, R.C.J.Somerville, K. Steffen, E.J. Steig, M. Visbeck, A.J. Weaver. 2009. The Copenhagen Diagnosis, 2009: Updating the World on the Latest Climate Science. The University of New South WalesClimate Change Research Centre (CCRC), Sydney, Australia, 60pp.

Armentano, T.V., J.P. Sah, M.S. Ross, D.T. Jones, H.C. Cooley, and C.S. Smith. 2006. Rapid response of vegetation to hydrological changes in Taylor Slough, Everglades National Park, Florida, USA. Hydrobiologia 569:293-309.

Attieh, J.M., A.D. Hanon, and H.S. Saini. 1995. Purification and characterization of a novel methyltransferase responsible for biosynthesis of halomethanes and methanethiol in Brassica oleracea. The Journal of Biological Chemistry 270: 9250-9257.

Blei, E. 2010. A study of methyl halide fluxes in temperate and tropical ecosystems. Doctoral Dissertation. University of Edinburgh.

Blei, E., M.R. Heal, and K.V. Heal. 2010. Long-term $\mathrm{CH}_{3} \mathrm{Br}$ and $\mathrm{CH}_{3} \mathrm{Cl}$ flux measurements in temperate salt marshes. Biogeosciences 7: 3657-3668.

Blei, E. and M.R. Heal. 2011. Methyl Bromide and methyl chloride fluxes from temperate forest litter. Atmospheric Environmental 45(8):1543-1547.

Brown P. and A.L. Wright. 2009. The role of periphyton in the Everglades. University of Florida: IFAS Extension: SL 310.

Bulter, J.H. 2000. Better budgets for methyl halides? Nature 403: 260-261.

Caldwell, M. and S. Flint. 1994. Stratospheric ozone reduction, solar UV-B radiation and terrestrial ecosystems. Climatic Change 28(4): 375-394.

Clerbaux, C. and D.M. Cunnold. 2007. In Scientific Assessment of Ozone Depletion: 2006. World Meteorological Organization: Geneva, 2007.

Daniel, J.S., G.J.M. Velders, S. Solomon, M. McFarland and S.A. Montzka. 2007. Present and future sources and emissions of halocarbons: Towards new constraints. Journal of Geophysical Research Atmospheres 112: D02301. 
Donar, C.M., K.W. Condon, M. Gantar, and E.E. Gaiser. 2004. A new technique for examining the physical structure of Everglades floating periphyton mat. Nova Hedwigia 78: 107-119.

Drewer, J., M.R. Heal, K.V. Heal, and K.A. Smith. 2006. Temporal and spatial variation in methyl bromide flux from a salt marsh. Geophysical Research Letters 33: L16808.

Ennis, C.A. 2007. Scientific Assessment of Ozone Depletion: 2006, chap. "Executive Summary". World Meteorological Organization: Geneva, 2007.

Ewe, S. M.L., E.E. Gaiser, D.L. Childers, V.H. Rivera-Monroy, D. Iwaniec, J.

Fourquerean, and R.R. Twilley. 2006. Spatial and temporal patterns of aboveground net primary productivity (ANPP) along two freshwater-estuarine transects in the Florida Coastal Everglades LTER (2001-2004). Hydrobiologia 569:459-474.

Fahey, D.W. 2007. Scientific Assessment of Ozone Depletion: 2006, chap. "Twenty questions and answers about the ozone layer". World Meteorological Organization: Geneva, 2007.

Gaiser, E.E., D.L. Childers, R.D. Jones, J.H. Richards, L.J.Scinto, and J.C. Trexler. 2006. Periphyton responses to eutrophication in the Florida Everglades: cross-system patterns of structural and compositional change. Limnology and Oceanography 51(1, part 2): 617-630.

Gaiser, E., P.V. McCormick, S.E. Hagerthey, and A.D. Gottlieb. 2011. Landscape patterns of periphyton in the Florida Everglades. Critical Reviews in Environmental Science and Technology 41(S1): 92-120.

Goldsborough, L.G. and G.G.C. Robinson. 1996. Chapter 4. Pattern in wetlands. Pages 77-177 in R.J. Stevenson, M.L. Bothwell, and R.L. Lowe (eds), Algal Ecology:

Freshwater Benthic Ecosystems, Academic Press, San Diego, CA.

Hader D.-P., H.D. Kumar, R.C. Smith, and R.C. Worrest. 2003. Aquatic ecosystems: effects of solar ultraviolet radiation and interactions with other climatic change factors. Photochemical and Photobiological Sciences 2: 39-50.

Hader D.-P., H.D. Kumar, R.C. Smith, and R.C. Worrest. 2007. Effects of solar UV radiation on aquatic ecosystems and interactions with climate change. Photochemical and Photobiological Sciences 6: 267-285.

Hagerthey, S.E., B.J. Bellinger, K. Wheeler, M. Gantar, and E. Gaiser. 2011. Everglades periphyton: a biogeochemical perspective. Critical Reviews in Environmental Science and Technology 41(S1): 309-343. 
Hamilton, J.T.G., W.C. McRoberts, F. Keppler, R.M. Kalin, and D.B. Harper. 2003. Chloride methylation by plant pectin: an efficient environmentally significant process. Science 301: 206-209.

Hammes, F., M. Vital, T. Egli. 2010. Critical evaluation of the volumetric "bottle effect" on microbial batch growth. Applied and Environmental Microbiology 76(4): 1278-1281.

Harper, D.B. 2000. The global chloromethane cycle: biosynthesis, biodegradation and metabolic role. Natural Product Reports 17: 337-348.

Herndl G.J., G. Muller-Niklas, and J. Frick. 1993. Major role of ultraviolet-B in controlling bacterioplankton growth in the surface layer of the ocean. Nature 361: 717719.

Hu, L., S.A. Yvon-Lewis, Y. Liu, J.E. Salisbury, and J.E. O’Hern. 2010. Coastal emissions of methyl bromide and methyl chloride along the eastern Gulf of Mexico and the east coast of the United States. Global Biogeochemical Cycles 24: GB1007.

Huset, R.A. 2007. Methyl halides: concentrations, fluxes, and stable carbon isotope ratios measured in the atmosphere, coastal waters, and soils. Doctoral Dissertation. University of Washington.

Jones, R.D. and J.A. Amador. 1992. Removal of total phosphorus and phosphate by peat soils of the Florida Everglades. Canadian Journal of Fisheries and Aquatic Sciences 49: 577-583.

Krammer, M., B. Velimirov, U. Fischer, A. H. Farnleitner, A. Herzig, and A. K. Kirschner. 2008. Growth response of soda lake bacterial communities to simulated rainfall. Microbial Ecology 55:194-211.

La Hee, J.M and E.E. Gaiser. 2012. Benthic diatom assemblages as indicators of water quality in the Everglades and three tropical karstic wetlands. Freshwater Science 31(1):205-221.

Lee S.S., E.E. Gaiser, and J.C. Trexler. 2013. Diatom-based models for inferring hydrology and periphyton abundance in a subtropical karstic wetland: implications for ecosystem-scale bioassessment. Wetlands 33: 157-173.

Lee-Taylor, J.M., G.P. Brasseur, and Y. Yokouchi. 2001. A preliminary threedimensional global model study of atmospheric methyl chloride distributions. Journal of Geophysical Research 106: 34221-34233. 
Maie, N., N.M. Scully, O. Pisani, and R. Jaffe. 2007. Composition of a protein-like flurophore of dissolved organic matter in coastal wetland and estuarine ecotystes. Water Research 41: 563-570.

Manley, S.L. 2002. Phytogenesis of halomethanes: A product of selection or a metabolic accident? Biogeochemistry 60: 163-180.

Manley, S.L., N.-Y. Wang, M.L. Walser, and R.J. Cicerone. 2006. Coastal salt marshes as global methyl halide sources from determinations of intrinsic production by marsh plants. Global Biochemical Cycles 20: Gb3015.

Manley, S.L., N-Y. Wang, M.L. Walser, and R.J. Cicerone. 2007. Methyl halide emissions from greenhouse-grown mangroves. Geophysical Research Letters 34: L01806.

Marrase, C. L., L. Lim, and D. A. Caron. 1992. Seasonal and daily changes in bacterivory in a coastal plankton community. Marine Ecology Progress Series 82:281-289.

McCormick, P.V., R.B.E. Shuford, J.B. Backus, and W.C. Kennedy. 1998. Spatial and seasonal patterns of periphyton biomass and productivity in the northern Everglades, FL, USA. Hydrobiologia 362: 185-208.

Montzka, S.A., and S. Reimann. 2010. In Scientific Assessment of Ozone Depletion: 2010. World Meteorological Organization: Geneva, 2011.

$\mathrm{Ni}$, X. and L.P. Hager. 1999. Expression of Batis maritime methyl chloride transferase in Escherichia coli. Proceedings of the National Academy of Science 96: 3611-3615.

Noe, G.B., D.L. Childers, and R.D. Jones. 2001. Phosphorus Biogeochemistry and the impact of phosphorus enrichment: why is the Everglades so unique? Ecosystems 4:603624.

Paul, C. and G. Pohnert. 2011. Production and role of volatile halogenated compounds from marine algae. Natural Product Reports 28: 186-195.

Parsons, R. 2011. Ozone Depletion: Stratospheric Chlorine and Bromine FAQ.

Popov, A.P., A.V. Priezzhev, J. Lademann, and R. Myllyla. 2005. $\mathrm{TiO}_{2}$ nanoparticles as an effective UV-B radiation skin-protective compound in sunscreens. Journal of Applied Physics D: Applied Physics 38(500):2564-2570.

Redeker, K.R., N.Y. Wang, J.C. Low, A. McMillan, S.C. Tyler, and R.J. Ciceronel. 2000. Emissions of methyl halides and methane from rice paddies. Science 290: 966-969. 
Redeker, K.R, J. Andrews, F. Fisher, R. Sass, and R.J. Cicerone. 2002. Interfield and intrafield variability of methyl halide emissions from rice paddies. Global Biogeochemical Cycles 16: 72.1-72.9.

Redeker, K.R., S.L. Manley, M. Walser, and R.J. Cicerone. 2004a. Physiological and biochemical controls over methyl halide emissions from rice plants. Global Biogeochemical cycles 18: GB1007.

Redeker, K.R., K.K. Treseder, and M.F. Allen. 2004b. Ectomycorrhizal fungi: A new source of atmospheric methyl halides? Global Change Biology 10: 1009-1016.

Rhew, R.C, B.R. Miller, and R.F. Weiss. 2000. Natural methyl bromide and methyl chloride emissions from coastal salt marshes. Nature 403: 292-295.

Rhew, R.C., B.R. Miller, B. Markus, A.H. Goldstein, and R.F. Weiss. 2002.

Environmental and biological controls on methyl halide emissions from southern California coastal salt marshes. Biochemistry 60: 141-161.

Rhew, R.C and T. Abel. 2007. Measuring simultaneous production and consumption fluxes of methyl chloride and methyl bromide in annual temperate grasslands.

Environmental Science \& Technology 41:7837-7843.

Rhew, R.C. 2011. Sources and sinks of methyl bromide and methyl chloride in the tallgrass prairie: applying a stable isotope tracer technique over highly variable gross fluxes. Journal of Geophysical Research 116: G03026.

Saha, A.K., S. Saha, J. Sadle, J. Jiang, M.S. Ross, R.M. Price, L.S.L.O. Sternberg, and K.S. Wendelberger. 2011. Sea level rise and South Florida coastal forests. Climatic Change 107(1-2): 81-108.

Saini, H.S., J.M. Attieh, and A.D. Hanson. 1995. Biosynthesis of halomethanes and methanethiol by higher plants via a novel methyltransferase reaction. Plant, Cell, and Environment 18: 1027-1033.

Saxena, D., S. Aouak, J. Attieh, and H.S. Saini. 1998. Biochemical characterization of chloromethane emission from the wood-rotting fungus Phellinus pomaceus. Applied and Environmental Microbiology 64(8): 2831-2835.

Scheidt, D., J. Stober, R. Jones, and K. Thornton. 2000. South Florida Ecosystem Assessment: Everglades water management, soil loss, eutrophication, and habitat. United States Environmental Protection Agency: EPA 904-R-00-003. 
The Comprehensive Everglades Restoration Plan (CERP). 2010. Final 2009 System Status Report. Restoration Coordination and Verification (RECOVER). http://www.evergladesplan.org/pm/ssr_2009/ssr_pdfs/2009_ssr_full_web.pdf on May 18, 2013.

Tait V.K. and R.M. Moore. 1995. Methyl chloride $\left(\mathrm{CH}_{3} \mathrm{Cl}\right)$ production in phytoplankton cultures. Limnology and Oceanography 40(1): 189-195.

Thomas, V.M., J.A. Bedford, and R. J. Cicerone. 1997. Bromine emissions from leaded gasoline. Geophysical Research Letters 24: 1371-1374.

Trexler, J.C., E.E. Gaiser, and D.L. Childers (eds.). 2006. Rapid responses of vegetation to hydrological changes in Taylor Slough, Everglades National Park, Florida, USA. Hydrobiologia 569:293-309.

Warwick, N.J., J.A. Pyle, and D.E. Shallcross. 2006. Global modeling of the atmospheric methyl bromide budget. Journal of Atmospheric Chemistry 54: 133-159.

Wayne. R.P. 2000. Chemistry of Atmospheres. Oxford University Press: $3^{\text {rd }}$ ed.

White, M.L., R.K.Varner, P.M. Crill, and C.H. Mosedale. 2005. Controls on the seasonal exchange of $\mathrm{CH}_{3} \mathrm{Br}$ in temperate peatlands. Global Biogeochemical Cycles 19: GB4009.

Williams, M.B., A. Aydin, C. Tatum, and E.S. Saltzman. 2007. A 2000 year atmospheric history of methyl chloride from a South Pole ice core: Evidence for climate-controlled variability. Geophysical Research Letters 34: L07811.

Wuosmaa, A.M. and L.P. Hager. 1990. Methyl chloride transferase: A carbocation route for biosynthesis of halometabolites. Science 249: 160-162.

Yokouchi. Y., Y. Noikiri, L.A. Barrie, D. Toom-Sauntry, T. Machida, Y. Inuzuka, H. Akimoto, H.-J. Li, Y. Fujinuma, and S. Aoki. 2000. A strong source of methyl chloride to the atmosphere from tropical coastal land. Nature 403:295-298.

Yoshida, Y., Y.H. Wang, T. Zeng, and R. Yantosca. 2004. A three-dimensional global model study of atmospheric methyl chloride budget and distributions. Journal of Geophysical Research 109. 


\section{Appendix A}

\section{Tables}

Table A.1: Pre-concentration system valve positions for all water treatments and standards.

\begin{tabular}{|c|c|c|c|c|c|c|c|c|c|c|}
\hline & $\begin{array}{c}\text { Bath } \\
\text { type }\end{array}$ & V1 & V2 & $\mathbf{V 3}$ & V4 & V5 & V6 & V7 & V8 & V9 \\
\hline \multicolumn{11}{|l|}{$\begin{array}{l}\text { Gas standards } \\
(14 \mathrm{~mL} \text { loop })\end{array}$} \\
\hline initial & cold & 6 & load & inject & inject & closed & closed & load & inject & load \\
\hline 0.5 to 20 minutes & cold & & inject & load & inject & closed & closed & load & inject & load \\
\hline 20-25 minutes & hot & & load & load & inject & closed & closed & inject & load & inject \\
\hline after 25 minutes & hot & & load & load & inject & closed & closed & load & inject & load \\
\hline \multicolumn{11}{|l|}{ 100mL + $14 \mathrm{~mL}$ loop) } \\
\hline initial & cold & 6 & load & load & inject & closed & closed & load & inject & load \\
\hline 0.5 to 20 minutes & cold & & inject & inject & inject & closed & closed & load & inject & load \\
\hline $20-25 n$ & hot & & load & load & inject & closed & closed & inject & load & inject \\
\hline after 25 minutes & hot & & load & load & inject & closed & closed & load & inject & load \\
\hline \multicolumn{11}{|l|}{ Water samples } \\
\hline initial & cold & 1 & load & load & inject & closed & closed & load & inject & load \\
\hline 0.5 to 20 & cold & & load & load & load & open & closed & load & inject & load \\
\hline $20-25$ minutes & hot & & load & load & inject & closed & closed & inject & load & inject \\
\hline after 25 minutes & hot & & load & load & inject & closed & closed & load & inject & load \\
\hline
\end{tabular}


Table A.2: Operational and standby operating conditions for the GC-ECD system

\begin{tabular}{lrr}
\hline Operating conditions & Standby & Operational \\
\hline Pre-concentration system temperature & $35^{\circ} \mathrm{C}$ & $40^{\circ} \mathrm{C}$ \\
GC oven temperature & $70^{\circ} \mathrm{C}$ & $40^{\circ} \mathrm{C}$ \\
Detector temperature & $300^{\circ} \mathrm{C}$ & $250^{\circ} \mathrm{C}$ \\
$\mathrm{N}_{2} / \mathrm{O}_{2}$ makeup gas regulator setting & turned off & $\sim 20 \mathrm{psi}$ \\
$\mathrm{N}_{2}$ (tank 2) regulator setting & $\sim 40 \mathrm{psi}$ & turned off \\
$\mathrm{N}_{2}$ (tank 4) regulator setting & $\sim 6 \mathrm{psi}$ & turned off \\
$\mathrm{He}$ (tank 3) carrier gas regulator setting & $\sim 3 \mathrm{psi}$ & $\sim 20 \mathrm{psi}$ \\
$\mathrm{He}$ (tank 1) carrier gas regulator setting & $\sim 40 \mathrm{psi}$ & $\sim 40 \mathrm{psi}$ \\
\hline
\end{tabular}




\section{Appendix B}

\section{Daily operations of the GC-ECD}

\section{Startup Procedure}

1. Heating element found in the dewar surrounding the U-shaped water trap was turned off and removed.

2. Laboratory computer was turned on and Agilent EZChrom SI software was opened.

3. GC oven temperature was ramped up to $150^{\circ} \mathrm{C}$ for $\sim 15$ minutes to burn off any remaining artifacts and the detector temperature was changed to $250^{\circ} \mathrm{C}$. After 15 minutes, the $\mathrm{GC}$ oven temperature was lowered to $40^{\circ} \mathrm{C}$.

4. The temperature for the pre-concentration system was increased to $40^{\circ} \mathrm{C}$.

5. The GC trap was submerged in a hot water bath for 30 minutes to flush out any remaining artifacts. During this time period, the stripping chamber was purged if water samples were to be run.

6. Nitrogen (tank 4) gas line was shut off to the pre-concentration system and the helium (tank 3) gas line was increased to 20 psi. A two-way switch was then turned to allow for helium to enter the pre-concentration system.

7. Liquid nitrogen was then pulled in the dewar surrounding the U-shaped water trap and refilled periodically throughout the day.

8. Lastly, a two way switch was turned to allow for the makeup gas $\left(\mathrm{N}_{2} / \mathrm{O}_{2}\right)$ to enter the ECD instead of nitrogen (tank 2).

\section{Shutdown Procedure:}

1. Remaining liquid nitrogen from the U-shaped water trap was poured into another container.

2. The two way switch closest to the U shaped trap was then turned to allow for the helium (tank 3) gas line to vent. The helium tank was reduced to $\sim 3 p s i$.

3. The nitrogen (tank 4) gas line was opened back up to allow for flow through the pre-concentration system overnight.

4. The two way switch next to the makeup gas line and nitrogen (tank 2) line was switched back to the nitrogen gas line overnight. The makeup gas tank was shut off to prevent any gas seepage.

5. The temperature for the pre-concentration system was turned down to $35^{\circ} \mathrm{C}$, the GC oven temperature was raised to $70^{\circ} \mathrm{C}$, and the detector temperature was raised to $300^{\circ} \mathrm{C}$.

6. The heating element was placed in the dewar surrounding the U-shaped trap and turned on.

7. EZChrom SI software was shut down and the computer turned off. 